\title{
Methanotrophic contribution to biodegradation of phenoxy acids in cultures enriched from a groundwater-fed rapid sand filter
}

Papadopoulou, Aikaterini; Hedegaard, Mathilde Jørgensen; Dechesne, Arnaud; Albrechtsen, HansJørgen; Musovic, Sanin; Smets, Barth F.

Published in:

Applied Microbiology and Biotechnology

Link to article, DOI:

10.1007/s00253-018-9501-8

Publication date:

2019

Document Version

Peer reviewed version

Link back to DTU Orbit

Citation (APA):

Papadopoulou, A., Hedegaard, M. J., Dechesne, A., Albrechtsen, H-J., Musovic, S., \& Smets, B. F. (2019). Methanotrophic contribution to biodegradation of phenoxy acids in cultures enriched from a groundwater-fed rapid sand filter. Applied Microbiology and Biotechnology, 103(2), 1007-1019. https://doi.org/10.1007/s00253018-9501-8

\section{General rights}

Copyright and moral rights for the publications made accessible in the public portal are retained by the authors and/or other copyright owners and it is a condition of accessing publications that users recognise and abide by the legal requirements associated with these rights.

- Users may download and print one copy of any publication from the public portal for the purpose of private study or research.

- You may not further distribute the material or use it for any profit-making activity or commercial gain

- You may freely distribute the URL identifying the publication in the public portal 
1 Springer Editorial System for Applied Microbiology and Biotechnology

2 Title: Methanotrophic contribution to biodegradation of phenoxy acids in cultures enriched from a 3 groundwater-fed rapid sand filter

4 Article Type: Original Article

5 Keywords: methanotrophs; drinking water; pesticides; phenoxy acids; removal;

6 Authors: Aikaterini Papadopoulou ${ }^{1,2}$, Mathilde J. Hedegaard ${ }^{1 *}$, Arnaud Dechesne ${ }^{1}$, Hans-Jørgen 7 Albrechtsen ${ }^{1}$, Sanin Musovic ${ }^{1,3}$, Barth F. Smets ${ }^{1 *}$

$8 \quad{ }^{1}$ DTU Environment, Technical University of Denmark, DK-2800 Kgs. Lyngby, Denmark;

$9 \quad{ }^{2}$ Current address: Battelle UK Ltd, Chelmsford, CM2 5LB, United Kingdom

$10 \quad{ }^{3}$ Current address: The Danish Technological Institute, DK-2630 Taastrup, Denmark

11 Corresponding Authors: Mathilde J. Hedegaard (mjhe @env.dtu.dk) and Barth F. Smets

12 (bfsm@env.dtu.dk)

14 Address: DTU Environment

15 Technical University of Denmark

16 Building 113

17 DK-2800 Kgs. Lyngby

18 Denmark 


\section{Abstract}

Drinking water supply is in many parts of the world based on groundwater. Groundwater often contains methane, which can be oxidized by methanotrophs upon aeration. Sand from rapid sand filters fed with methane-rich groundwater can remove some pesticides (Hedegaard and Albrechtsen, 2014). We enriched methanotrophs from filter sand and investigated whether they could drive the degradation of various pesticides. To enrich for methanotrophs we designed and operated four laboratory-scale, continuously methane-fed column reactors, inoculated with filter sand and one control column fed with tap water. When enrichments were obtained, methane was continuously supplied to three reactors, while the fourth was starved for methane for one week, and the reactors were spiked with ten pesticides at groundwater-relevant concentrations (2.1-6.6 $\mu \mathrm{g} / \mathrm{L})$. Removal for most pesticides was not detected at the investigated contact time (1.37 minutes). However, the degradation of phenoxy acids was observed in the methanotrophic column reactor starved for methane, while it was not detected in the control column indicating the importance of methanotrophs. Phenoxy acid removal, using dichlorprop as model compound, was further investigated in batch experiments with methanotrophic biomass collected from the enrichment reactors. Phenoxy acid removal (expressed per gram of matrix sand) was substantially improved in the methanotrophic enrichment compared to parent filter sand. The presence of methane did not clearly impact dichlorprop removal but did impact mineralization. We suggest that other heterotrophs are responsible for the first step in dichlorprop degradation, while the subsequent steps including ringhydroxylation are driven by methanotrophs.

\section{Introduction}

In several countries, drinking water originates from groundwater. Groundwater can contain several unwanted inorganic and organic compounds, such as methane, hydrogen sulphide, ammonium, iron $\left(\mathrm{Fe}^{2+}\right)$ and manganese $\left(\mathrm{Mn}^{2+}\right)$. To remove these contaminants, the groundwater is often aerated to strip methane and hydrogen sulphide, and to add oxygen prior to subsequent rapid sand filtration, where physio-chemical and biological processes remove iron, manganese, ammonium, and residual methane. Groundwater sources may also contain pesticides. In Denmark, for example, pesticides and their transformation products were found in $28.5 \%$ of all active waterworks wells in the period 19922015 (GEUS \& Danish Ministry of Energy Utilities and Climate, 2016). EU regulations set the highest allowable concentration for a single pesticide in drinking water at $0.1 \mu \mathrm{g} / \mathrm{L}$ (European Commission, 2006, 2000). In Denmark, the policy is to close contaminated extraction wells when pesticide concentrations exceed EU norms (GEUS \& Danish Ministry of Energy Utilities and Climate, 2016). This is a unsustainable and costly approach, and novel solutions to remove pesticides from groundwater are attractive alternatives to obtain good drinking water quality (Benner et al., 2013).

Microorganisms can degrade many organic trace contaminants and utilize them as sources of carbon and possibly also nitrogen, phosphorus or sulfur, often leading to mineralization (Alexander, 1994). This is called primary metabolism and contrasts with co-metabolism where contaminants are transformed fortuitously by enzymes with broad substrate specificity along with the primary growth substrate, without being used as an energy, nutrient or carbon source (Ciavarelli et al., 2012; Dalton and Stirling, 1982; Rattier et al., 2014). Co-metabolism is particularly relevant when contaminants occur at very low concentrations (ng- $\mu \mathrm{g} / \mathrm{L}$ ) (Alexander, 1994; Benner et al., 2015; Nzila, 2013). 
Methanotrophs are typically present at aerobic/anaerobic interfaces where they thrive from methane oxidation (Semrau et al., 2010). Due to the non-specificity of the methane monooxygenase enzyme (MMO), methanotrophs can co-metabolically oxidize a suite of organic compounds (Hedegaard et al., 2018; Semrau et al., 2010). The methane monooxygenase (MMO) exists in two forms: a soluble cytoplasmic form (sMMO) and a particulate membrane-associated (pMMO) form (Hanson and Hanson, 1996; Jiang et al., 2010; Semrau et al., 2013). While almost all methanotrophs have a gene encoding pMMO, only some have genes encoding sMMO (Pandey et al., 2014). Expression of sMMO occurs at low copper $(\mathrm{Cu})$ to biomass ratios, whereas pMMO expression increases when this ratio increases (Semrau et al., 2013; Sirajuddin and Rosenzweig, 2015). sMMO has a broader substrate range than pMMO, and the cometabolic activity of methanotrophs has therefore typically been ascribed to sMMO (Jiang et al., 2010; Semrau et al., 2010).

Upon aeration, methane in the groundwater can be utilized to grow methanotrophs in bioreactors. By taking advantage of the co-metabolic properties of methanotrophs, this approach could create an opportunity for simultaneous degradation of pesticides. However, cometabolic degradation may be slow because of enzymatic preference for the primary substrate. One way to evaluate the co-metabolic transformation of a trace contaminant (TC) is by measuring its transformation yield $\left(T_{y}\right.$, in moles TC removed per mole methane oxidized), which expresses the relative stoichiometry between consumption of the primary and secondary substrate (Anderson and Mccarty, 1997). The transformation yield depends on several factors, and especially the concentrations of the primary and secondary substrates. At environmentally relevant conditions, the concentration of pesticides (below $\mu \mathrm{g} / \mathrm{L})$ relative to the concentration of methane $(\mathrm{mg} / \mathrm{L})$ is typically very low, and thus the competition from methane oxidation is likely to limit co-metabolic pesticide removal ( Jiang et al., 2010; Semprini and McCarty, 1992; Suttinun et al., 2013).

Inspired by the observed removal and mineralization of pesticides (bentazone, dichlorprop, mecoprop (MCPP), glyphosate and $p$-nitrophenol) in microcosms with sand material sampled from biological rapid sand filters from a waterworks with methane-rich groundwater (Hedegaard and Albrechtsen, 2014), we assessed the potential for methanotroph driven co-metabolic removal for a range of pesticides at environmentally relevant concentrations. To this end, we developed a methanotrophic enrichment culture in lab-scale continuous-flow column reactors using rapid sand filter material as inoculum and methane as the sole intentional carbon source. With this methanotrophic enrichment culture, we established whether a suite of pesticides at environmentally relevant concentrations could be removed, with focus on phenoxy acids.

\section{Material and methods}

\section{Reactor experiments}

\section{Reactor set-up and operational conditions}

Five replicate cylindrical up-flow column reactors made of Plexiglass $(\mathrm{r}=2 \mathrm{~cm}$ and $\mathrm{h}=8 \mathrm{~cm}$ ) were packed with $37.8 \mathrm{~g}$ porous expanded clay carrier material (Filtralite NC 0.8-1.6, Saint-Gobain Weber, Norway) with a bulk density of $530 \mathrm{~kg} / \mathrm{m}^{3}$ (dry and compressed Filtralite, according to the manufacturer) chosen for its high specific surface area $\left(1.89 \mathrm{~m}^{2} / \mathrm{g}\right)$. Four of the column reactors were inoculated $(2 \% \mathrm{v} / \mathrm{v})$ with material originating from rapid sand filters (prefilters) of a waterworks (Sjælsø, Zealand, Denmark, operated by Novafos) treating groundwater with high methane 
concentration (1.1-9.2 mg/L) (Hedegaard and Albrechtsen, 2014). The fifth reactor served as control and was filled with autoclaved carrier material and fed with tap water only (no methane).

The column reactors were fed with non-chlorinated tap water through a pressure-reducing valve at a flow rate of $21 \mathrm{~mL} / \mathrm{min}$, resulting in a hydraulic retention time of max $1.37 \mathrm{~min}$. Methane (from gastight bags) was mixed in the tap water through individual $80 \mathrm{~cm}$ high plastic bubble columns, with counter-current flow of water and methane driven by two peristaltic pumps (Figure S1). The water/methane mixture was continuously fed to the column reactors at a target influent concentration of $1.5 \mathrm{mg}$ methane/L. Low gas-permeability polyurethane tubing (i.d. $4 \mathrm{~mm}$, o.d. $6 \mathrm{~mm}$, Alfapur (PU), Alfaflex, Mechelen, BE) was used to deliver the water/methane mixture. Tubing was replaced every third week to avoid excess biofilm growth. Tap water contained traces of $\mathrm{NO}_{3}{ }^{-} \mathrm{-N} / \mathrm{L}$ ( 0.57 to 0.96 $\mathrm{mg} / \mathrm{L})$, and $\mathrm{PO}_{4}-\mathrm{P} / \mathrm{L}(<0.01$ (method detection limit) to $0.04 \mathrm{mg} / \mathrm{L})$ as analysed with test kits (Spectroquant, Merck, GE).

\section{Monitoring of dissolved methane and dissolved oxygen in reactors}

To monitor methane removal, $3 \mathrm{~mL}$ water samples were collected weekly from the influent and effluent ports. Influent ports were placed approximately $7 \mathrm{~cm}$ before the water/methane mixture entry to the reactors while effluent samples were collected by inserting the tip of a gas-tight syringe directly into the effluent tubing. To avoid loss of dissolved methane during sample collection from the influent port, samples were collected with a $5 \mathrm{~cm}$ long needle with a gas tight syringe inserted into the tube from the sampling port. Dissolved oxygen (DO) in the effluents from the reactors was measured in a flow-through set-up with a DO probe (HQ40d portable multi meter with a LDO101 probe, HACH, Loveland, Colorado, USA).

\section{Assessment of pesticide removal of column reactors}

Removal of ten pesticides was investigated in the column reactors: 2,6-dichlorobenzamide (BAM, degradation product of dichlobenil), bromoxynil, chlorotoluron, diuron, ioxynil, isoproturon, linuron, 4-chloro-2-methylphenoxy acetic acid (MCPA) and mecoprop (MCPP) (Table 1 for IUPAC names). The pesticides (all from Dr. Ehrenstorfer GmbH, Augsburg, GE) were dissolved separately (6.3 mg/L for each compound) in ultrapure water at $30^{\circ} \mathrm{C}$ and stirred overnight. After 270 days of reactor operation, the pesticide mixture was continuously supplied to the influent of each reactor to reach a concentration of $5 \mu \mathrm{g} / \mathrm{L}$ for each compound (flow rate of $1 \mathrm{~mL} /$ hour). Three of the column reactors remained continuously fed with methane, one reactor was starved for methane for a week prior to addition, and the fifth reactor remained as abiotic control. The pesticide supply lasted 72 hours during which effluent samples were collected every 24 hours, while the influent was only sampled on the last day. All compounds were analyzed by Eurofins Miljø (Galten, DK). 


\begin{tabular}{|c|c|c|c|c|c|}
\hline Pesticide & IUPAC Name & Formula & $\begin{array}{c}\mathbf{M}^{*} \\
(\mathrm{~g} / \mathrm{mol})\end{array}$ & $\begin{array}{c}\text { Category } \\
\text { Herbicide }\end{array}$ & Chemical Structure \\
\hline BAM & 2,6-dichlorobenzamide & $\mathrm{C}_{7} \mathrm{H}_{5} \mathrm{Cl}_{2} \mathrm{NO}$ & 172.011 & $\begin{array}{l}\text { Degradation } \\
\text { product of } \\
\text { dichlobenil }\end{array}$ & \\
\hline Bromoxynil & $\begin{array}{c}\text { 3,5-dibromo-4- } \\
\text { hydroxybenzonitrile }\end{array}$ & $\mathrm{C}_{7} \mathrm{H}_{3} \mathrm{Br}_{2} \mathrm{NO}$ & 276.913 & Nitrile & \\
\hline Ioxynil & $\begin{array}{l}\text { 4-hydroxy-3,5- } \\
\text { diiodobenzonitrile }\end{array}$ & $\mathrm{C}_{7} \mathrm{H}_{3} \mathrm{I}_{2} \mathrm{NO}$ & 370.914 & Nitrile & \\
\hline Chlorotoluron & $\begin{array}{l}\text { 3-(3-chloro-p-tolyl)-1,1- } \\
\text { dimethylurea }\end{array}$ & $\mathrm{C}_{10} \mathrm{H}_{13} \mathrm{ClN}_{2} \mathrm{O}$ & 212.677 & Phenyl-urea & \\
\hline Diuron & $\begin{array}{l}\text { 3-(3,4-dichlorophenyl)- } \\
\text { 1,1-dimethylurea }\end{array}$ & $\mathrm{C}_{9} \mathrm{H}_{10} \mathrm{Cl}_{2} \mathrm{~N}_{2} \mathrm{O}$ & 233.095 & Phenyl-urea & \\
\hline Isoproturon & $\begin{array}{c}\text { 1,1-dimethyl-3-(4-propan- } \\
\text { 2-ylphenyl)urea }\end{array}$ & $\mathrm{C}_{12} \mathrm{H}_{18} \mathrm{~N}_{2} \mathrm{O}$ & 206.284 & Phenyl-urea & \\
\hline Linuron & $\begin{array}{l}\text { 3-(3,4-dichlorophenyl)-1- } \\
\text { methoxy-1-methylurea }\end{array}$ & $\mathrm{C}_{9} \mathrm{H}_{10} \mathrm{Cl}_{2} \mathrm{~N}_{2} \mathrm{O}_{2}$ & 249.094 & Phenyl-urea & \\
\hline MCPA & $\begin{array}{c}\text { 2-(4-chloro-2- } \\
\text { methylphenoxy)acetic } \\
\text { acid }\end{array}$ & $\mathrm{C}_{9} \mathrm{H}_{9} \mathrm{ClO}_{3}$ & 200.619 & $\begin{array}{l}\text { Phenoxx } \\
\text { acid }\end{array}$ & \\
\hline MCPP & $\begin{array}{c}\text { 2-(4-chloro-2- } \\
\text { methylphenoxy)propanoic } \\
\text { acid }\end{array}$ & $\mathrm{C}_{10} \mathrm{H}_{11} \mathrm{ClO}_{3}$ & 214.645 & $\begin{array}{l}\text { Phenoxy } \\
\text { acid }\end{array}$ & \\
\hline
\end{tabular}

\section{Potential pesticide removal in column reactors}

138 To evaluate whether the co-metabolic methanotrophic activity in the column reactors would have 139 been sufficient to observe pesticide removal, we calculated expected pesticide removal rates. We 140 based our analysis on observed normalized substrate preferences, $S P_{C H 4 / T C}$, based on input data 141 reported in literature (Anderson and Mccarty, 1997; Hedegaard et al., 2018). The normalized substrate 142 preference measures the preference for oxidation of the primary substrate (methane) over the 
143 oxidation of the secondary substrate (pesticide, Pes) and is given by (modified from Hedegaard et al., 144 2018):

$$
S P_{\frac{C H_{4}}{P e s}}=\frac{\frac{C_{P e s}}{C_{C H 4}}}{{ }_{y, \frac{P e s}{C H_{4}}}}=\frac{\frac{C_{P e s}}{C_{C H 4}}}{\frac{C_{P e s}}{r_{C H_{4}}}}
$$

146 Hence, the rate of pesticide removal can be expressed as:

$$
r_{P e s}=\frac{r_{\mathrm{CH}_{4}} \times \frac{C_{P e s}}{C_{C H 4}}}{S_{C_{C H} / P e s}}
$$

Where $S P$, $C H 4 / P e s$ is the observed normalized substrate preference, $T_{y, P e s / C H 4}$ is the transformation yield, which measures the removal rate of the trace contaminant, $\mathrm{r}_{P e s}$, relative to the removal rate of methane, $\mathrm{r}_{\mathrm{CH} 4}$, (Anderson and Mccarty, 1997) and $C_{P e s} \mathrm{C}_{\mathrm{CH} 4}$ is the ratio of the pesticide to methane concentration. In these calculations, the average inlet concentration of methane $(0.9 \mathrm{mg} / \mathrm{L})$ and the average methane removal rate $(25 \mu \mathrm{M} / \mathrm{min})$ in the column reactors were applied (Table 2$)$. From the expected pesticide removal rate, the expected pesticide removal, $\Delta \mathrm{C}_{\text {expect,pes, }}$, was calculated using the maximal hydraulic retention time of 1.37 minutes.

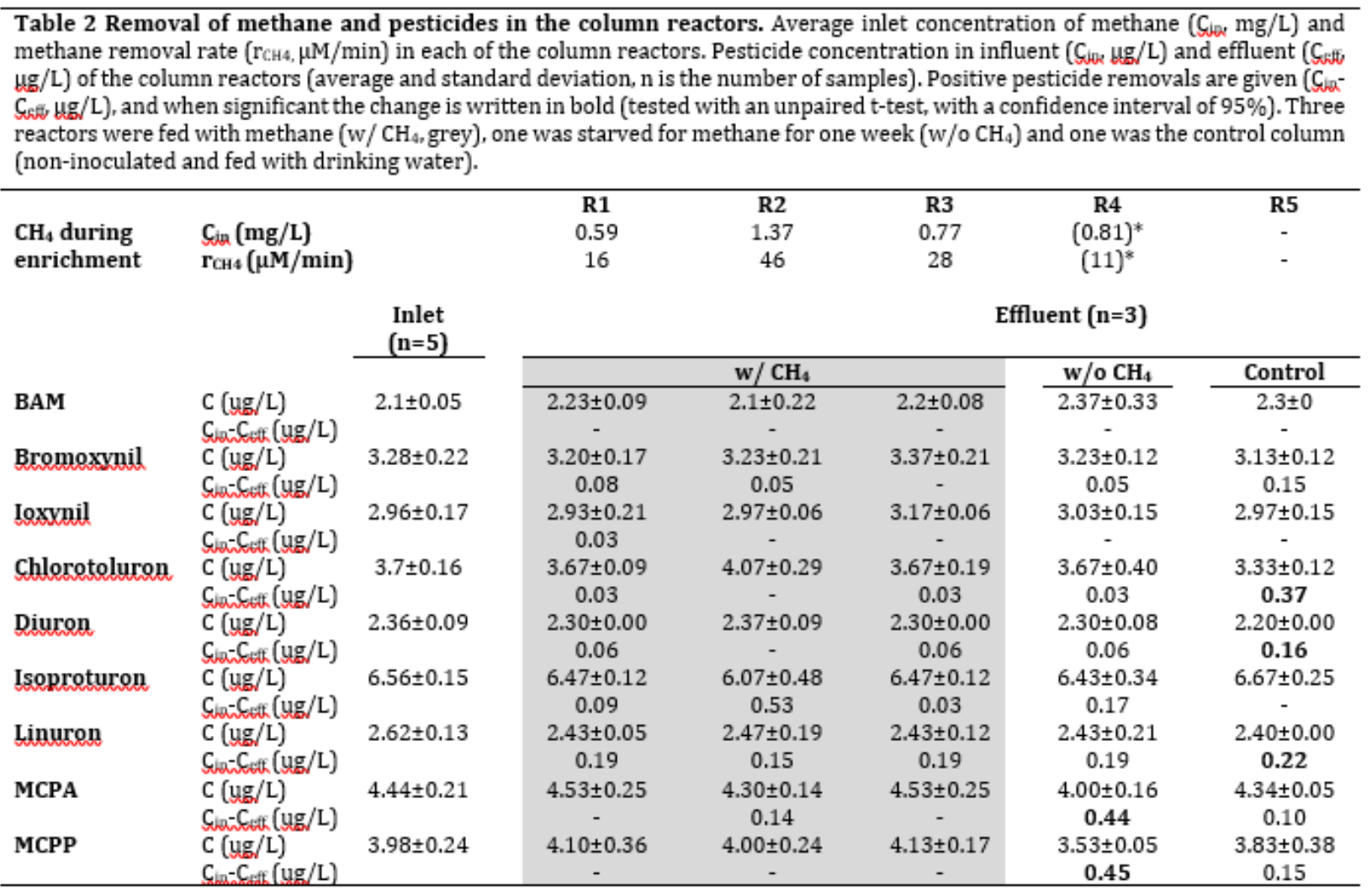




\section{7}

158

159

160

161

162

163

164

165

166

167

168

169

170

171

172

173

174

175

176

177

178

179

180

181

182

183

184

185

186

187

188

189

190

191

192

193

194

195

196

197

198

\section{Microcosm experiments}

Removal and mineralization of dichlorprop (2-(2,4-dichlorophenoxy)propanoic acid) by the methanotrophic enrichment were investigated in batch experiments. The column reactors were operated for more than 400 days before they were sacrificed to initiate batch experiments. Within a period of two hours, approx. $20 \mathrm{~g}$ aliquot of wet carrier material and biomass $\left(\mathrm{g}_{\mathrm{B} \& \mathrm{C}}\right)$ was collected from each of all methane-fed column reactors. The different aliquots were combined and manually mixed with a autoclaved spoon, and $10 \mathrm{~g}$ aliquots transferred to six $300 \mathrm{~mL}$ serum bottles (microcosms). Prior to the experiment all serum bottles had been acid-washed and heated to $555^{\circ} \mathrm{C}$ for 12 hours. Abiotic controls were set up with virgin Filtralite carrier material and were autoclaved (20 min, 1 bar and $121^{\circ} \mathrm{C}$ ). Tap water was added to a total volume of $100 \mathrm{~mL}$. The microcosms were closed with Teflon stoppers and aluminum lids. The microcosms were incubated at room temperature (approx. $22^{\circ} \mathrm{C}$ ) on an orbital shaker set at $120 \mathrm{rev} / \mathrm{min}$. The $\mathrm{pH}$, measured with $\mathrm{pH}$ strips at the beginning of each experiment, was 7-8. Dichlorprop removal was investigated by spiking ${ }^{14} \mathrm{C}-$ dichlorprop, in general at $0.9 \mu \mathrm{g} / \mathrm{L}$, to microcosms three times (Figure S2). The first spike of ${ }^{14} \mathrm{C}$ dichlorprop occurred a few hours after assembling the microcosms; the second spike after eight days, and the last spike after 57 days. In all three spikes, microcosms with and without methane addition were included. The first spike included triplicate microcosms of each treatment, while the second spike included only single microcosms of each treatment (because the two other microcosms were used in other experiments). Before the last spike, the microcosm content (liquid with suspended biomass) was collected from each of the microcosms (with and without methane) and used in new microcosms each containing $1 / 5$ of the content. In this experiment four microcosms with methane and three microcosms without methane were included, while the remaining biomass was used for qPCR analysis. The effect of pesticide concentrations on the removal was studied during the last spike: three different concentrations $(0.4 \mu \mathrm{g} / \mathrm{L} ; 0.9 \mu \mathrm{g} / \mathrm{L}$ and $3.5 \mu \mathrm{g} / \mathrm{L})$ of ${ }^{14} \mathrm{C}$-dichlorprop were examined in single microcosms (except for a concentration of $0.9 \mu \mathrm{g} / \mathrm{L}{ }^{14} \mathrm{C}$-dichlorprop with methane, which was in duplicates) (Figure S2).

Between two spikes, the microcosms were briefly aerated with atmospheric air to strip the previously produced ${ }^{14} \mathrm{CO}_{2}$, before re-spiking with radiolabeled compounds and methane. Water was replenished to reach a total volume of $100 \mathrm{~mL}$ and a water sample was collected before a new ${ }^{14} \mathrm{C}$-dichlorprop spike to measure residual radioactivity from the previous spikes.

Methane was added to the microcosms before each ${ }^{14} \mathrm{C}$-dichlorprop spike (targeting a concentration of $1.5 \mathrm{mg}$ methane/L, as in the column reactors) and oxygen and methane concentrations were monitored during the experiments to avoid depletion. During the first and second spike, a mixture of pure oxygen and methane (to match the required 1:2 methane to oxygen e stoichiometric volumratio for complete oxidation) was added every 2 to 5 days to microcosms with methane to maintain atmospheric pressure. During the third spike, methane was only added initially, targeting a concentration of $5 \mathrm{mg}$ methane/L, and atmospheric air was added during the experiment to maintain atmospheric pressure.

\section{Chemicals}

In microcosm experiments, removal and mineralization were investigated with [ring-U- $\left.{ }^{14} \mathrm{C}\right]-$ dichlorprop (Izotop, Institute of Isotopes Co., Ltd., Hungary) with a nominal radiochemical purity of 
97.96\%. Stock solutions were prepared in methanol. Methanol was removed by volatilization, and the ${ }^{14} \mathrm{C}$-dichlorprop was subsequently dissolved in sterile MilliQ water and added to the microcosms.

\section{Sampling}

Two liquid samples of a total volume of $6-10 \mathrm{~mL}$ were collected in syringes by piercing the microcosm caps. $3 \mathrm{~mL}$ water samples were collected for methane analysis and 3-7 mL samples were collected for dichlorprop analysis. The extracted volume was replaced by atmospheric air. Samples were filtered ( $0.22 \mu \mathrm{m}$ Nylon GF filter, diameter $25 \mathrm{~mm}$, Frisenette Aps).

\section{Measurement of ${ }^{14} \mathrm{C}$-activity}

The produced ${ }^{14} \mathrm{CO}_{2}$ in the water phase was quantified by a double vial system, where produced ${ }^{14} \mathrm{CO}_{2}$ in the water is stripped off and captured by a base trap ( $1 \mathrm{~mL} 2 \mathrm{M} \mathrm{NaOH})$ (Janniche et al. 2010). In microcosm experiments, pesticide concentration at a given sampling time was expressed as a fraction of the initial concentration and corrected for the removal caused by sampling (given as ${ }^{14} \mathrm{C} /{ }^{14} \mathrm{C}_{0}(\%)$ ). Mineralization was calculated as the cumulative ${ }^{14} \mathrm{CO}_{2}$ produced normalized to the initial ${ }^{14} \mathrm{C}$ dichlorprop and corrected for the ${ }^{14} \mathrm{C}$ removed during sampling and the change in volume of liquid and gaseous phase (given as ${ }^{14} \mathrm{CO}_{2} /{ }^{14} \mathrm{C}_{0}(\%)$ ). Scintillation liquid (Optiphase HiSafe 3, Perkin Elmer) was added to the samples ( $4 \mathrm{~mL}$ to base traps and $10 \mathrm{~mL}$ to the water samples) and ${ }^{14} \mathrm{C}$-activity was quantified by liquid scintillation (Hidex 300 SL, 1414 Liquid Scintillation Counter, controlled by MikroWin 2000 software, Hidex, Turku, FIN).

\section{Methane and oxygen analysis}

Water samples (vol.) collected for methane analysis were transferred to $6 \mathrm{~mL}$ vacuum serum vials and $0.3 \mathrm{~mL}$ of phosphoric acid was added to halt further biological methane oxidation. The samples were kept upside down (to keep the gas trapped) at $5^{\circ} \mathrm{C}$ until analysis. When returned to room temperature, a headspace gas sample of $2 \mu \mathrm{L}$ was collected with a gas-tight syringe and inserted into the GC-FID. Dissolved methane concentrations were calculated based on measured gaseous concentrations and Henry's Law.

In microcosms, dissolved oxygen concentration was monitored with Oxygen-Sensitive Mini-sensors read with a fiber optic oxygen meter (Fibox 3 Loligo Systems ApS, Viborg, DK).

\section{Estimation of methanotroph abundance and diversity}

Filter material from rapid sand filters (parent material) and column reactors (enrichments, collected from two reactors after 450 days of operation) was separately blended and drained prior to storage at $-20^{\circ} \mathrm{C}$. The microcosms were sampled by collecting $20 \mathrm{~mL}$ of liquid suspension. The biomass was centrifuged at $4.000 \mathrm{rpm}$ for $5 \mathrm{~min}$., re-suspended in sterile-filtered distilled $\mathrm{H}_{2} \mathrm{O}$, subjected to a final centrifugation prior to storage at $-20^{\circ} \mathrm{C}$. All bacteria (Eubacteria - targeting the 16S rRNA gene) and methanotrophs (targeting $p m o A$, the gene coding for subunit alpha of the methane monooxygenase) were quantified by real-time quantitative PCR (qPCR) (see SI). The diversity of pmoA was investigated by cloning and sequencing (see SI). Microbial abundances were calculated under the assumption of an average of two copies of $16 \mathrm{~S}$ rRNA (Klappenbach et al., 2001; Lee et al., 2006) or pmoA (Semrau et al., 1995; Stolyar et al., 1999) gene per genome (cell).

Sequences of pmoA have been deposited in DDBJ under accession numbers LC384897-LC384917 (Table S1). 


\section{Data treatment}

240 We used the statistical software GraphPad Prism 5 for data treatment, this included calculation of first order rate constants based on removal in microcosm experiments.

\section{Results}

\section{Reactor performance and enrichment of methanotrophs}

All column reactors removed methane (Table 2, Figure S3); most was removed in Reactor 2 (R2) where the consumption of oxygen and methane was closest to the expected stoichiometric ratio ( 2 mole $\mathrm{O}_{2} /$ mole $\mathrm{CH}_{4}$ ) (Figure S4). However, in all column reactors, the consumption of oxygen was larger than required to oxidize the influent methane, which suggests the presence of additional biodegradable matter in the tap water, which might support a heterotrophic microbial population in the columns.

The total bacterial density in the rapid sand filters (RSF) was approx. 1.29x $10^{8} 16 \mathrm{~S}$ rRNA gene copies $/ \mathrm{g}_{\text {sand }}$ and the $p m o A$ density was $1.7 \times 10^{6}$ copies $/ \mathrm{g}_{\text {sand. }}$. Upon enrichment (450 days), the $p m o A$ density increased more than one order of magnitude (to $5.1 \times 10^{7} \mathrm{pmoA}$ copies $/ \mathrm{g}_{\mathrm{B} \& \mathrm{C}}$ ). Hence, the fraction of methanotrophs increased from $1.3 \%$ in the RSF to $12 \%$ in the column reactors (Figure 1).

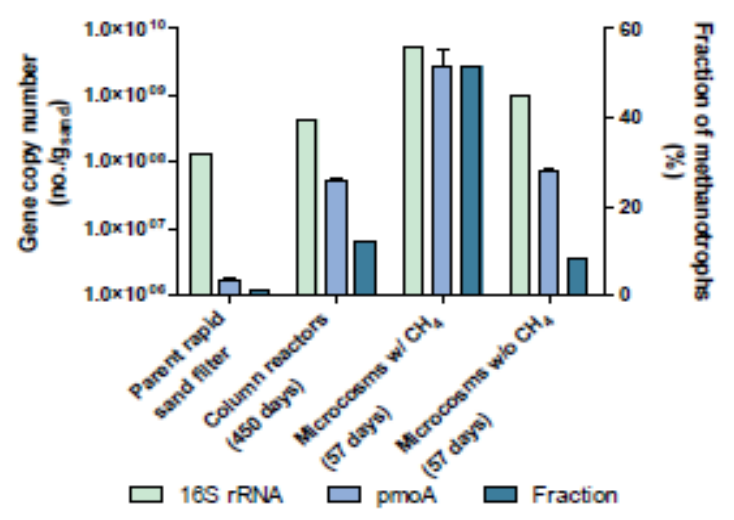

Fig. 1 Microbial density during the experimental phases. The change in microbial density is illustrated by the abundance of total bacteria (expressed by 16S rRNA gene copies), methanotrophs (expressed by pmoA gene copies) and the fraction of methanotrophs (normalized to the total number of bacteria) in the parent rapid sand filter, the column reactors (after 450 days) and microcosms with and without methane (after 57 days).

\section{Pesticide removal in the column reactors}

The removal behavior of the 10 investigated pesticides could be categorized in three groups. The first group contained BAM, bromoxynil, chlorotoluron and ioxynil: they were not removed in any of the column reactors. The second group comprised diuron, isoproturon and linuron: all were partly removed, both in reactors with methane and in reactors starved for methane (starved for one week). However, the removal of these pesticides was lower or at the same level as removal in the noninoculated control column (fed with tap water), and could thus not be ascribed to the methanotrophic 
enrichment (Table 2). The third group comprised the two phenoxy acids, MCPA and MCPP. These compounds were not significantly removed in either the control or in presence of methane, but each was significantly removed in the methanotrophic enrichment reactor that had been starved for methane (MCPA: $\mathrm{P}=0.0213$, unpaired $t$-test; MCPP: $\mathrm{P}=0.0208$, unpaired $t$-test). In the methane enrichment, MCPA decreased by $0.44 \mu \mathrm{g} / \mathrm{L}$ (from $4.44 \mu \mathrm{g} / \mathrm{L}$ ) and MCPP by $0.45 \mu \mathrm{g} / \mathrm{L}$ (from 3.98 $\mu \mathrm{g} / \mathrm{L}$ ) within the short contact time of the column reactors (Table 2). Hence, methane starvation appears to stimulate removal of the investigated phenoxy acids in methanotrophic enrichment columns.

We investigated whether the undetectable removal for most pesticides could be explained by the experimental conditions. Therefore we calculated the minimum detectable pesticide removal,

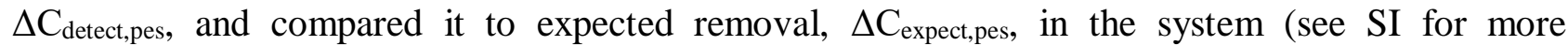
information, Table S2). Based on these calculations we conclude that the typical degree of cometabolic activity by methanotrophs would not have been sufficient to observe pesticide removal in the reactors (except for BAM and isoproturon) in view of the contact time and analytical precision.

\section{Dichlorprop removal and mineralization}

280 In the column reactors, a clear biodegradation potential was only noted for phenoxy acids (MCPA 281 and MCPP). Among phenoxy acids, dichlorprop is the most frequently detected in Danish groundwater (GEUS \& Danish Ministry of Energy Utilities and Climate, 2016). Therefore, the methanotrophic dichlorprop degradation was further investigated in microcosm experiments, where it contact time could be increased and both pesticide removal and mineralization could be measured.

Dichlorprop was rapidly removed in all microcosms with the methanotrophic enrichment culture. In biologically active microcosms more than $86 \%$ of the dichlorprop was removed during the first four hours, while in abiotic controls only $13 \%$ removal was measured. Dichlorprop removal reached $98 \%$ within 48 hours in both microcosms with or without methane addition (Figure 2). After 100 hours, $46 \%$ of the initially added ${ }^{14} \mathrm{C}$-dichlorprop was recovered as ${ }^{14} \mathrm{CO}_{2}$ in the microcosms without methane while only $29 \%$ was recovered in microcosms with methane addition. The absence of methane enhanced the mineralization of dichlorprop (Figure 2). 


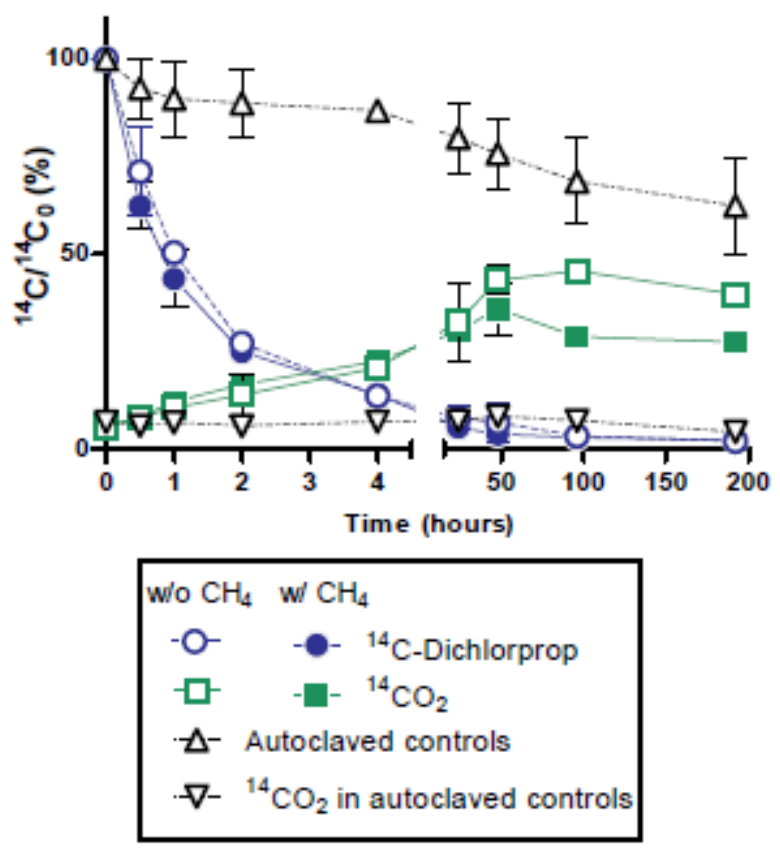

Fig. 2 Dichlorprop removal and mineralization by the methanotrophic enrichment culture in batch microcosms. Dichlorprop removal and mineralization in microcosms with $10 \mathrm{~g}$ methanotrophic enrichment culture and carrier material, $100 \mathrm{~mL}$ tap water and ${ }^{14} \mathrm{C}$-dichlorprop (initial concentration $0.9 \mu \mathrm{g} / \mathrm{L}$ ) with $\left(\mathrm{w} / \mathrm{CH}_{4}\right)(1.5 \mathrm{mg} / \mathrm{L})$ and without methane (w/o CH 4 ). Mean values and standard deviation of the dichlorprop concentration in the water $\left({ }^{14} \mathrm{C} /{ }^{14} \mathrm{C}_{0}\right)$ and the ${ }^{14} \mathrm{CO}_{2}$ production $\left({ }^{14} \mathrm{CO}_{2} /{ }^{14} \mathrm{C}_{0}\right)$ from mineralization of dichlorprop (all in triplicates).

To investigate whether dichlorprop removal potential was further affected by extended methane deprivation, methane was periodically resupplied in microcosms with methane, while microcosms without methane were continuously starved, before dichlorprop was spiked again (second spike) and removal evaluated. Now, initial dichloroprop removal was delayed in microcosms with antecedent methane addition, compared to the microcosm with antecedent methane starving. However, within 48 hours, $96 \%$ of the dichlorprop was removed in both types of microcosms (Figure S5). Again, mineralization was substantially higher in the absence (40\%) compared to the presence $(8.4 \%)$ of methane (Table 3 and Figure S5). Methane spiking versus starvation continued and, before a third spike, microcosm contents were divided into several replicates (Figure S2) to investigate how different concentrations of dichlorprop $(0.4-3.5 \mu \mathrm{g} / \mathrm{L})$ affected removal. During this third spike, in microcosms with dichlorprop concentrations of 0.4 and $0.9 \mu \mathrm{g} / \mathrm{L}$, removal was similar in presence and absence of methane, but at $3.5 \mu \mathrm{g} / \mathrm{L}$ initial dichlorprop removal was slower in the presence than in the absence of methane (Figure S6A). Again at all tested concentrations, dichlorprop was mineralized to a larger extent in absence versus presence of methane, but with increasing dichlorprop concentrations less ${ }^{14} \mathrm{CO}_{2}$ was produced (Table 3 and Figure S6B). Across all three experiments, methane was present in eight microcosms (Figure S2) and in six out of these eight microcosms methane did not impact the dichlorprop removal.

315 In two out of the eight microcosms we observed an inhibition of methane on the initial dichlorprop removal (consistent with observations in the column reactors) (Figure S5 and S6). However, no 
obvious conditions could explain why these two microcosms behaved different from the other

\begin{tabular}{|c|c|c|c|c|c|c|}
\hline \multirow{4}{*}{$\begin{array}{l}\text { Initial concentration } \\
\mathrm{w} / \mathrm{CH}_{4} \\
\mathrm{w} / \mathrm{o} \mathrm{CH}_{4}\end{array}$} & \multirow{4}{*}{$\begin{array}{c}(\mu \mathrm{g} / \mathrm{L}) \\
(\%) \\
(\%)\end{array}$} & \multirow{2}{*}{$\begin{array}{c}\text { 1st }^{\text {st }} \text { pike } \\
0.9\end{array}$} & \multirow{2}{*}{$\frac{2^{\text {nd }} \text { Spike }}{0.9}$} & \multicolumn{3}{|c|}{$3^{\text {rd }}$ Spike } \\
\hline & & & & 0.4 & 0.9 & 3.5 \\
\hline & & 27 & 8.4 & 13 & 11 & 7.5 \\
\hline & & 40 & 40 & 29 & 14 & 15 \\
\hline
\end{tabular}

\section{Development of the bacterial community over the experimental phases}

As mentioned previously, the total bacterial density as well as the $p m o A$ density increased during the enrichment, compared to the RSF inoculum, resulting in an increase in the methanotroph fraction (versus eubacteria) from $1.3 \%$ in the RSF to $12 \%$ in the column reactors (Figure 1). Periodic methane spiking of the microcosms further increased the abundance of both methanotrophs $\left(2.8 \times 10^{9} \mathrm{pmoA}\right.$ copies $\left./ \mathrm{g}_{\mathrm{B} \& \mathrm{C}}\right)$ and eubacteria $\left(5.5 \times 10^{9}\right.$ gene copies $\left./ \mathrm{g}_{\mathrm{B} \& \mathrm{C}}\right)$ (measured before the third spike, after 57 days in the microcosms). In the methane-starved microcosms, methanotroph and eubacterial abundances were in the same range as in the column reactors, and the pmoA $\left(7.6 \times 10^{7} \mathrm{pmoA}\right.$ copies $/ \mathrm{g}_{\mathrm{B} \& \mathrm{C}}$ ) density was thus more than 10 -fold lower than in microcosms fed with methane (Figure 1). In microcosms with methane, the increased abundance of methanotrophs was also reflected in the methane consumption rates, which increased 3-fold from day $0\left(0.4 \mu \mathrm{g} \mathrm{CH} / / \mathrm{min} / \mathrm{g}_{\text {carrier material }}\right)$ to day

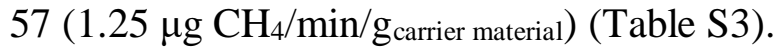

Besides density, the methanotrophic diversity also changed substantially between the experimental phases. In the RSF, all sequences belonged to 3 OTUs related to Methylomicrobium sp., known to only produce pMMO (Figure 3 and Table S4). Sequences from the column enrichment grouped in 9 OTUs with $70 \%$ related to Methylomonas sp (only pMMO producer), and $30 \%$ related to Methylocystis sp (both sMMO and pMMO producer) (Figure 3 and Table S4). Methane spiking to the microcosms retained a community similar to the one observed the column reactors, but with reduced diversity with 6 OTUs of which most (94\%) related to Methylomonas sp (pMMO) and the rest $(6 \%)$ to Methylocystis sp (sMMO and pMMO). With methane starvation, the methanotrophic diversity to 2 OTUs, both related to Methylocystis sp (sMMO and pMMO) (Figure 3 and Table S4). This suggests that methane addition favored selection of pMMO producing methanotrophs, while the methane starvation favored selection (or survival) of both sMMO and pMMO producing methanotrophs.

\section{Discussion}

\section{Methanotrophic contribution to phenoxy acid degradation}

346 Phenoxy acid biodegradation in the environment has been studied thoroughly, with a primary focus on primary metabolism, especially the degradation pathway encoded by $t f d$-like genes (BatioğluPazarbaşi et al., 2012; De Lipthay et al., 2003; Müller and Kohler, 2004; Paulin et al., 2010). The 
main catabolic steps in the degradation of phenoxy acids are similar, so for dichlorprop, degradation is likely initiated by a removal of the side chain, releasing 2,4-dichlorophenol, which is further hydroxylated and metabolized through opening of the aromatic nucleus (De Lipthay et al., 2003; Müller and Kohler, 2004; Paulin et al., 2011; Smejkal et al., 2001). To our knowledge, methanotrophs have not previously been linked to phenoxy acid removal or mineralization. We observed that starvation of the methanotrophic biomass stimulated biodegradation of MCPP and MCPA in the column reactors, while the lack of removal in both the control column and in methane-fed columns indicated that neither sorption nor general heterotrophic activity were essential for the removal. We investigated this mechanism further in microcosm experiments with dichlorprop.

Methane feeding and starvation of the methanotrophic enrichment culture affected dichlorprop degradation in different ways. In methane-fed microcosms, we expected that the presence of methane would competitively inhibit dichlorprop degradation. However, we also expected that long-term (more than 57 days) addition versus deprivation of methane to the methanotrophic enrichment, would result in increased dichlorprop degradation in methane-fed compared to the methane-deprived microcosms.

In general dichlorprop removal rates were similar in presence and absence of methane. Yet, the degree of dichlorprop mineralization $\left({ }^{14} \mathrm{CO}_{2}\right.$-production) was in all cases reduced by the presence of methane (Figure 2 and Table 3). Since sMMO and pMMO are oxygenases, we expected the methanotrophic activity to be responsible for the first step in the biodegradation of dichlorprop, converting dichlorprop to 2,4-dichlorophenol, but because presence of methane did not seem to affect dichlorprop removal in most cases, other heterotrophs were likely responsible for the first step of dichlorprop degradation. Yet, methane had an inhibitory effect on the degree of dichlorprop mineralization, which suggests that the subsequent ring-hydroxylation (of 2,4-dichlorophenol, the presumed dichlorprop metabolite) was associated with methanotrophs (and likely due to MMO activity, which would show less activity against 2,4-dichlorophenol due to competitive inhibition in the presence of methane). A previous study proposed a similar degradation pathway for $(R)-(+)-$ MCPP, where dioxygenases would be responsible for the initial cleavage of the compound, while monooxygenases were responsible for subsequent ring-hydroxylation (Tett et al., 1997).

The density of methanotrophs was higher in methane-fed compared to methane-starved microcosms. However, in microcosms starved for methane, the community became dominated by Methylocystis $s p$ types, which can express sMMO - capable of oxidizing aromatic compounds (Burrows et al., 1984; Semrau et al., 2010). Meanwhile, in methane-fed microcosms the community was dominated (94\%) by methanotrophs related to Methylomonas $s p$, which only carry genes encoding pMMO (Figure 3). Thus, while continuous feeding increased the number of methanotrophs compared to methanestarvation, this increase was mainly reflected in pMMO-producing methanotrophs. The similar cometabolic capacity of methane-starved and methane-fed microcosms thus indicated, that sMMO, rather than pMMO, was responsible for dichlorophenol degradation. A direct quantification of pMMO versus sMMO encoding genes would provide more definitive insight in the dynamics and role of the different methanotrophic metabolisms. 


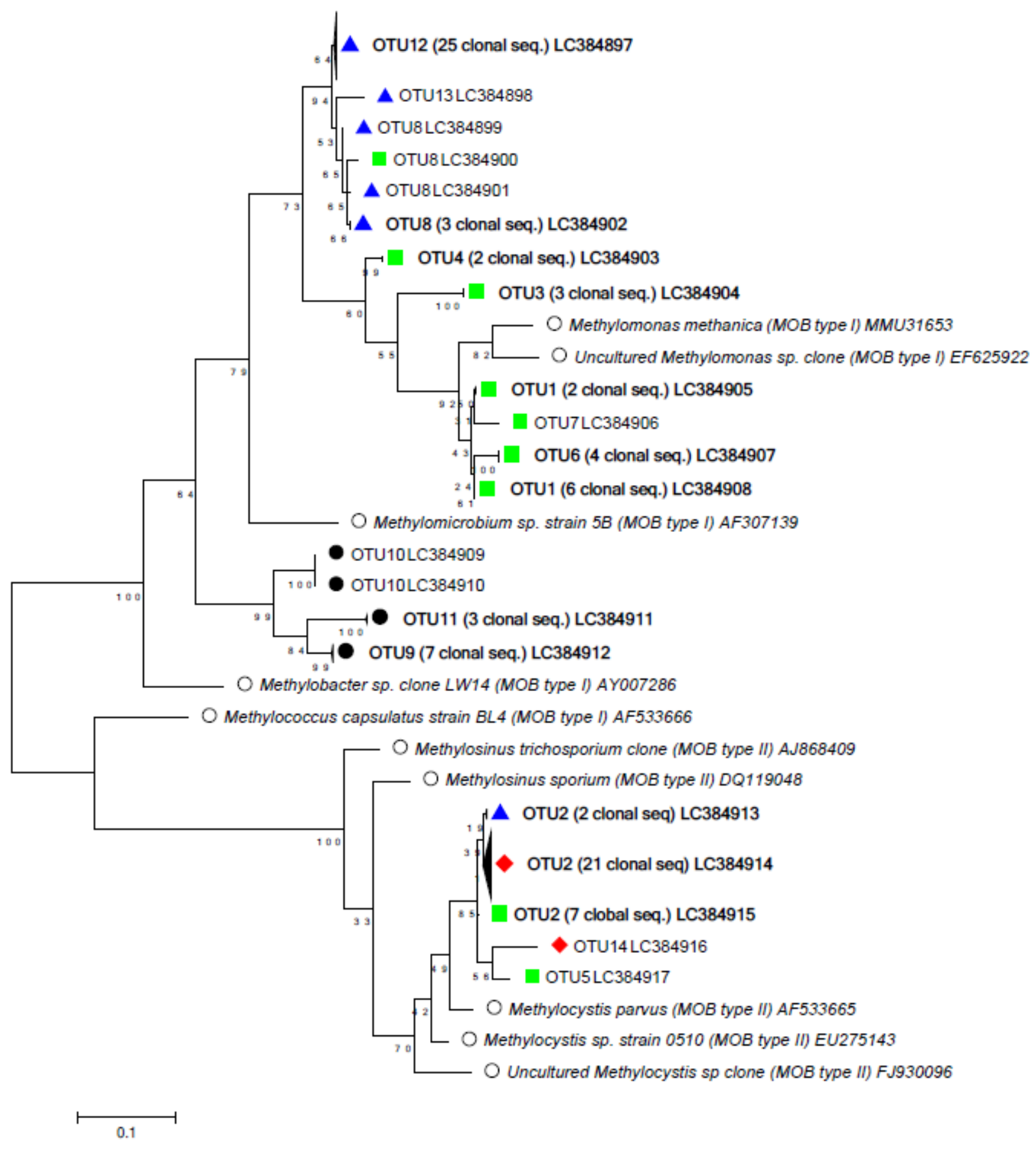

Fig. 3 Development of methanotrophs in the experiments. Neighbor-joining phylogenetic tree inferred from pmoA gene sequences cloned from rapid sand filter $(\boldsymbol{O})$, enrichment reactors $(\square)$, microcosms with methane $(\boldsymbol{\Delta})$ and microcosms without methane $(\diamond)$. The phylogenetic tree was created using MEGA 5.1 software, using the maximum likelihood function, based on the Tamura-Nei model (Tamura and Nei, 1993). Bootstrap analyses consisted of 500 replicates. Numbers of identical sequences (cutoff value 0.03) in each OTU are specified. Reference strains (o) are presented by name. The scale bar represents 0.1 expected substitutions per site. 


\section{Challenges for the application of methanotrophic column reactors in drinking water production}

The removal rate of MCPA and MCPP in the column reactors, and the mineralization of dichlorprop in microcosm experiments were larger in absence compared to presence of methane, indicating that presence of methane inhibited pesticide removal and mineralization. Using reported trace contaminant removal rates by methanotrophs, the methane oxidation in the column reactors was estimated to be insufficient for detectable degradation of most of the pesticides, within the contact time of the system. Hence, we observed a conflict between providing sufficient methane to support methanotrophic growth and securing sufficient quantities of MMO to degrade the pesticides, and the inhibitory effects of the presence of methane. Similar challenges are reported for methanotrophic bioremediation of contaminants in other systems (Jiang et al., 2010; Sullivan et al., 1998), and have been partially overcome by the use of sequential systems where growth and co-metabolic biodegradation takes place in different reactors (Jiang et al., 2010; Smith and McCarty, 1997).

The retention time in full-scale water filtration systems is typically short, varying from 7.5 to 20 minutes in rapid sand filters (Winter et al., 2010), compared to the time needed for pesticide degradation. The methanotrophic enrichment culture exhibited phenoxy acid removal rate constants (per gram filter material) that were two orders of magnitude higher than observed for material from waterworks with little or no methane in the raw water (Kerteminde, Islevbro and Sjæls $\emptyset$ waterworks Plant I, Table 4 and Table S5), and 5 to 30 times higher than observed for material from a waterworks receiving methane-rich groundwater (Sjælsø waterworks Plant II, Table 4 and Table S5) (Hedegaard and Albrechtsen, 2014). Normalizing the removal rate constants to the $p m o A$ gene densities, resulted in values within one order of magnitude for filter material and the enrichment culture (Table 4), supporting the involvement of methanotrophs in phenoxy acid removal in the full-scale rapid sand filters. Thus, the methanotrophic enrichment culture substantially improved phenoxy acid removal efficiency compared to parent filter sand, and applying methanotrophs in water treatment systems might therefore be a strategy for obtaining a rapid degradation.

The methanotrophic enrichment reactors had removal potential for some of the ten investigated pesticides. Two phenoxy acids, MCPA and MCPP, were degraded significantly in the methanotrophic enrichment reactors, when starved for methane, but when fed methane during the pesticide addition no substantial removal occurred. Thus, methanotrophs were essential for degradation and secondary heterotrophs (e.g. growing on decay products of methanotrophs) were not sufficient. For most pesticides the expected removal was lower than the detectable removal under the applied conditions. 
Applied Microbiology and Biotechnology (2019) 103: p. 1007-1019

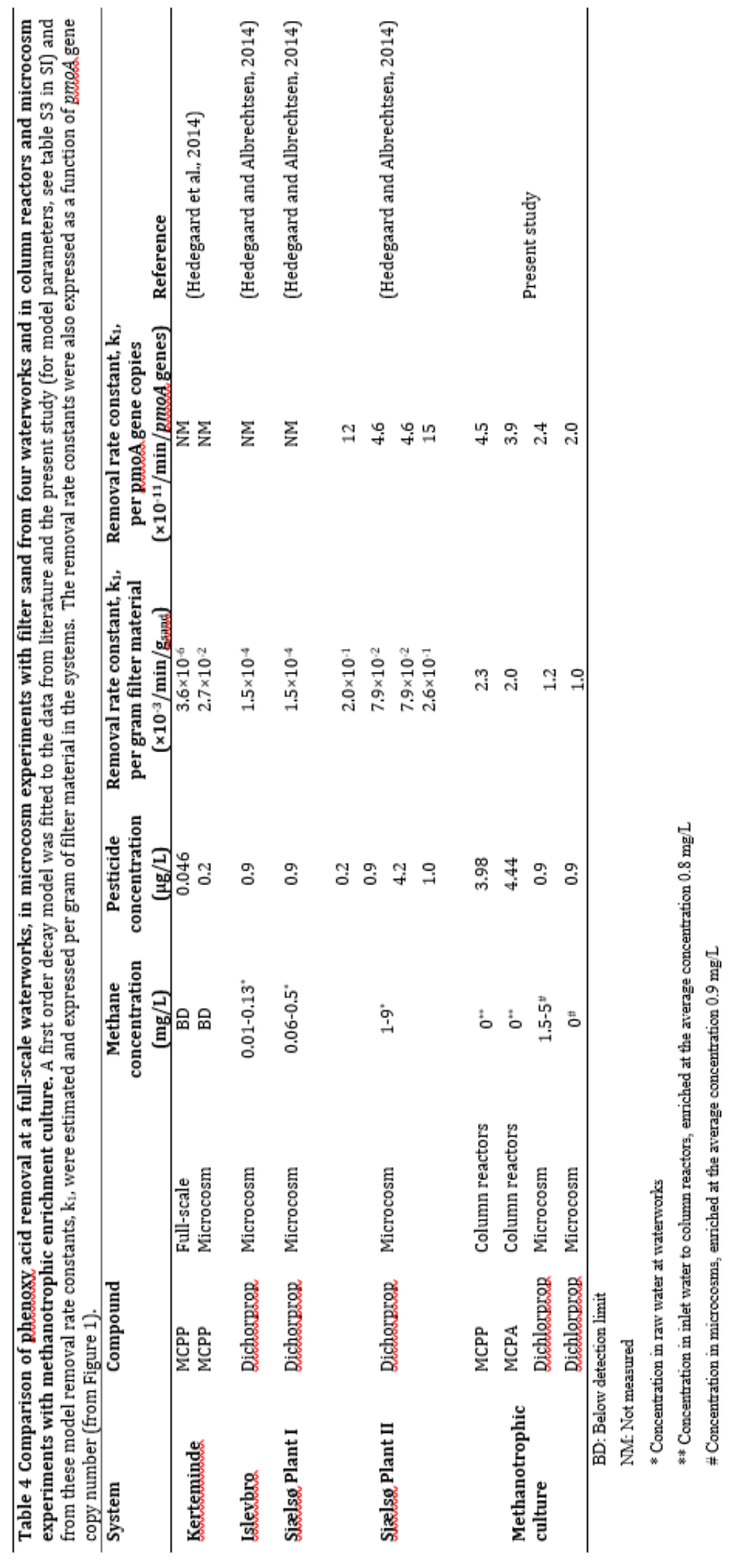


To increase the contact time, we investigated degradation of the phenoxy acid dichlorprop in microcosm experiments. Up to $86 \%$ of dichlorprop was removed within 4 hours, and the removal rates were similar in presence and absence of methane across all experiments. However, in all cases dichlorprop was mineralized to larger extent in absence versus presence of methane. We suggest that microbes other than methanotrophs are responsible for the first degradation step of dichlorprop. However, the inhibitory effects of methane on the dichlorprop mineralization, suggests that subsequent reactions (ring-hydroxylation and beyond) are facilitated by methanotrophs.

Applying methanotrophs in water treatment systems may hold promise for removal of phenoxy-acid pesticides, if suitable contact times are provided.

\section{Compliance with Ethical Standards}

Funding: This work was funded by project MIRESOWA (MIcrobial REmediation of contaminated SOil and WAter resources, Dansk Strategisk Forskningsråd grant number 2104-08-0012) and the Grundfos prize to HANA.

Conflict of Interest: Aikaterini Papadopoulou declares that she has no conflict of interest. Mathilde J. Hedegaard declares that she has no conflict of interest. Arnaud Dechesne declares that he has no conflict of interest. Hans-Jørgen Albrechtsen declares that he has no conflict of interest. Sanin Musovic declares that he has no conflict of interest. Barth F. Smets declares that he has no conflict of interest.

Ethical approval: This article does not contain any studies with human participants or animals performed by any of the authors.

\section{References}

Alexander, M., 1994. Biodegradation and bioremediation, 2nd ed. Academic Press.

Anderson, J.E., Mccarty, P.L., 1997. Transformation yields of chlorinated ethenes by a methanotrophic mixed culture expressing particulate methane monooxygenase. Appl. Environ. Microbiol. 63, 687-693.

Batioğlu-Pazarbaşi, M., Bælum, J., Johnsen, A.R., Sørensen, S.R., Albrechtsen, H.J., Aamand, J., 2012. Centimetre-scale vertical variability of phenoxy acid herbicide mineralization potential in aquifer sediment relates to the abundance of $t f d A$ genes. FEMS Microbiol. Ecol. 80, 331-341. https://doi.org/10.1111/j.1574-6941.2012.01300.x

Benner, J., De Smet, D., Ho, A., Kerckhof, F.M., Vanhaecke, L., Heylen, K., Boon, N., 2015. Exploring methane-oxidizing communities for the co-metabolic degradation of organic micropollutants. Appl. Microbiol. Biotechnol. 99, 3609-3618. https://doi.org/10.1007/s00253014-6226-1

Benner, J., Helbling, D.E., Kohler, H.E., Wittebol, J., Kaiser, E., Prasse, C., Ternes, T.A., Albers, C.N., Aamand, J., Horemans, B., Springael, D., Walravens, E., Boon, N., 2013. Is biological 
Applied Microbiology and Biotechnology (2019) 103: p. 1007-1019

treatment a viable alternative for micropollutant removal in drinking water treatment processes? Water Res. 47, 5955-5976. https://doi.org/10.1016/j.watres.2013.07.015

Burrows, K.J., Cornish, A., Scott, D., Higgins, I.J., 1984. Substrate specificities of the soluble and particulate methane mono-oxygenases of Methylosinus trichosporium OB3b. J. Gen. Microbiol. 130, 3327-3333. https://doi.org/10.1099/00221287-130-12-3327

Ciavarelli, R., Cappelletti, M., Fedi, S., Pinelli, D., Frascari, D., 2012. Chloroform aerobic cometabolism by butane-growing Rhodococcus aetherovorans BCP1 in continuous-flow biofilm reactors. Bioprocess Biosyst. Eng. 35, 667-681. https://doi.org/10.1007/s00449-0110647-3

Dalton, H., Stirling, D.I., 1982. Co-metabolism. Philos. Trans. R. Soc. London. Ser. B Biol. Sci. 297, 481-496.

De Lipthay, J.R., Tuxen, N., Johnsen, K., Hansen, L.H., Albrechtsen, H.J., Bjerg, P.L., Aamand, J., 2003. In situ exposure to low herbicide concentrations affects microbial population composition and catabolic gene frequency in an aerobic shallow aquifer. Appl. Environ. Microbiol. 69, 461467. https://doi.org/10.1128/AEM.69.1.461-467.2003

European Commission, 2006. Directive 2006/118/EC of the European Parliament and of the council of 12 December 2006 on the protection of groundwater against pollution and deterioration. Off. J. Eur. Union 19, 19-31. https://doi.org/http://eur-lex.europa.eu/legalcontent/EN/TXT/?uri=CELEX:32006L0118

European Commission, 2000. Directive 2000/60/EC of the European Parliament and of the Council of 23 October 2000 establishing a framework for Community action in the field of water policy. Off. J. Eur. Parliam. L327, 1-82. https://doi.org/10.1039/ap9842100196

GEUS \& Danish Ministry of Energy Utilities and Climate, 2016. Groundwater monitoring 1989 2015.

Hanson, R.S., Hanson, T.E., 1996. Methanotrophic bacteria. Microbiol.Rev. 60, 439-471.

Hedegaard, M.J.;, Deliniere, H., Prasse, C., Dechesne, A., Smets, B.F.., Albrechtsen, H.-J., 2018. Evidence of co-metabolic bentazone transformation by methanotrophic enrichment from a groundwater-fed rapid sand filter. Water Res. 129, 105-114. https://doi.org/10.1016/j.watres.2017.10.073

Hedegaard, M.J., Albrechtsen, H.-J., 2014. Microbial pesticide removal in rapid sand filters for drinking water treatment--potential and kinetics. Water Res. 48, 71-81. https://doi.org/10.1016/j.watres.2013.09.024

Hedegaard, M.J., Arvin, E., Corfitzen, C.B., Albrechtsen, H.-J., 2014. Mecoprop (MCPP) removal in full-scale rapid sand filters at a groundwater-based waterworks. Sci. Total Environ. 499. https://doi.org/10.1016/j.scitotenv.2014.08.052

Jiang, H., Chen, Y., Jiang, P., Zhang, C., Smith, T.J., Murrell, J.C., Xing, X.-H., 2010. 
Applied Microbiology and Biotechnology (2019) 103: p. 1007-1019

Methanotrophs: Multifunctional bacteria with promising applications in environmental bioengineering. Biochem. Eng. J. 49, 277-288. https://doi.org/10.1016/j.bej.2010.01.003

Klappenbach, J.A., Saxman, P.R., Cole, J.R., Schmidt, T.M., 2001. rrndb: the Ribosomal RNA Operon Copy Number Database. Nucleic Acids Res. 29, 181-184. https://doi.org/10.1093/nar/29.1.181

Lee, C., Kim, J., Shin, S.G., Hwang, S., 2006. Absolute and relative QPCR quantification of plasmid copy number in Escherichia coli. J. Biotechnol. 123, 273-280. https://doi.org/10.1016/j.jbiotec.2005.11.014

Müller, T. a, Kohler, H.-P.E., 2004. Chirality of pollutants--effects on metabolism and fate. Appl. Microbiol. Biotechnol. 64, 300-16. https://doi.org/10.1007/s00253-003-1511-4

Nzila, A., 2013. Update on the cometabolism of organic pollutants by bacteria. Environ. Pollut. 178, 474-482. https://doi.org/10.1016/j.envpol.2013.03.042

Pandey, V.C., Singh, J.S., Singh, D.P., Singh, R.P., 2014. Methanotrophs: Promising bacteria for environmental remediation. Int. J. Environ. Sci. Technol. 11, 241-250. https://doi.org/10.1007/s13762-013-0387-9

Paulin, M.M., Nicolaisen, M.H., Sorensen, J., 2010. Abundance and Expression of Enantioselective $r d p A$ and $s d p A$ Dioxygenase Genes during Degradation of the Racemic Herbicide $(R, S)-2-(2,4-$ Dichlorophenoxy)Propionate in Soil. Appl. Environ. Microbiol. 76, 2873-2883. https://doi.org/10.1128/AEM.02270-09

Paulin, M.M., Nicolaisen, M.H., Sørensen, J., 2011. (R,S)-dichlorprop herbicide in agricultural soil induces proliferation and expression of multiple dioxygenase-encoding genes in the indigenous microbial community. Environ. Microbiol. 13, 1513-1523. https://doi.org/10.1111/j.14622920.2011.02456.x

Rattier, M., Reungoat, J., Keller, J., Gernjak, W., 2014. Removal of micropollutants during tertiary wastewater treatment by biofiltration: Role of nitrifiers and removal mechanisms. Water Res. https://doi.org/10.1016/j.watres.2014.01.030

Semprini, L., McCarty, P.L., 1992. Comparison between model simulations and field results for insitu biorestoration of chlorinated aliphatics: Part 2. Comeetabolic transformations. Groundwater 30, 37-44.

Semrau, J.D., Chistoserdov, A., Lebron, J., Costello, A., Davagnino, J., Kenna, E., Holmes, A.J., Finch, R., Murrell, J.C., Lidstrom, M.E., 1995. Particulate methane monooxygenase genes in methanotrophs . J. Bacteriol. 177, 3071-3079.

Semrau, J.D., Dispirito, A.A., Yoon, S., 2010. Methanotrophs and copper. FEMS Microbiol. Rev., 34, 496-531. https://doi.org/10.1111/j.1574-6976.2010.00212.x

Semrau, J.D., Jagadevan, S., Dispirito, A.A., Khalifa, A., Scanlan, J., Bergman, B.H., Freemeier, B.C., Baral, B.S., Bandow, N.L., Vorobev, A., Haft, D.H., Vuilleumier, S., Murrell, C.J., 2013. 
Applied Microbiology and Biotechnology (2019) 103: p. 1007-1019

Methanobactin and MmoD work in concert to act as the "copper-switch" in methanotrophs. Environ. Microbiol. 15, 3077-3086. https://doi.org/10.1111/1462-2920.12150

Sirajuddin, S., Rosenzweig, A.C., 2015. Enzymatic oxidation of methane. Biochemistry 54, $2283-$ 2294. https://doi.org/10.1021/acs.biochem.5b00198

Smejkal, C.W., Vallaeys, T., Burton, S.K., Lappin-Scott, H.M., 2001. Substrate specificity of chlorophenoxyalkanoic acid-degrading bacteria is not dependent upon phylogenetically related tfdA gene types. Biol. Fertil. Soils 33, 507-513. https://doi.org/10.1007/s003740100360

Smith, L.H., McCarty, P.L., 1997. Laboratory evaluation of a two-stage treatment system for TCE cometabolism by a methane-oxidizing mixed culture. Biotechnol. Bioeng. 55, 650-659. https://doi.org/10.1002/(SICI)1097-0290(19970820)55:4<650::AID-BIT7>3.0.CO;2-G

Stolyar, S., Costello, A.M., Peeples, T.L., Lidstrom, M.E., 1999. Role of multiple gene copies in particulate methane monooxygenase activity in the methane-oxidizing bacterium Methylococcus capsulatus Bath. Microbiology 145, 1235-1244. https://doi.org/10.1099/13500872-145-5-1235

Sullivan, J.P., Dickinson, D., Chase, H.A., 1998. Methanotrophs, Methylosinus trichosporium OB3b, sMMO, and their application to bioremediation. Crit. Rev. Microbiol. https://doi.org/10.1080/10408419891294217

Suttinun, O., Luepromchai, E., Müller, R., 2013. Cometabolism of trichloroethylene: Concepts, limitations and available strategies for sustained biodegradation. Rev. Environ. Sci. Biotechnol. https://doi.org/10.1007/s11157-012-9291-X

Tamura, K., Nei, M., 1993. Estimation of the number of nucleotide substitutions in the control region of mitochondrial DNA in humans and chimpanzees. Mol. Biol. Evol. 10, 512-26. https://doi.org/10.1093/molbev/ms1149

Tett, V.A., Willetts, A.J., Lappin-Scott, H.M., 1997. Biodegradation of the chlorophenoxy herbicide (R)-(+)-mecoprop by Alcaligenes denitrificans. Biodegradation 8, 43-52. https://doi.org/10.1023/A:1008262901202

Winter, L., Linde, J.J., Winter, H., 2010. Water Supply Technology (in Danish), 5. edition. ed. Polyteknisk Forlag, Kgs. Lyngby, Denmark. 
Applied Microbiology and Biotechnology (2019) 103: p. 1007-1019

Springer Editorial System for Applied Microbiology and Biotechnology

Supplementary material for

Methanotrophic contribution to biodegradation of phenoxy acids in cultures enriched from a groundwater-fed rapid sand filter

doi: $10.1007 / \mathrm{s} 00253-018-9501-8$

Aikaterini Papadopoulou ${ }^{1,2}$, Mathilde J. Hedegaard ${ }^{1 *}$, Arnaud Dechesne ${ }^{1}$, Hans-Jørgen Albrechtsen ${ }^{1}$, Sanin Musovic ${ }^{1,3}$, Barth F. Smets ${ }^{1 *}$

${ }^{1}$ DTU Environment, Technical University of Denmark, DK-2800 Kgs. Lyngby, Denmark;

${ }^{2}$ Current address: Battelle UK Ltd, Chelmsford, CM2 5LB, United Kingdom

${ }^{3}$ Current address: The Danish Technological Institute, DK-2630 Taastrup, Denmark

*Corresponding Authors: Mathilde J. Hedegaard (mjhe@env.dtu.dk) and Barth F. Smets

(bfsm@env.dtu.dk)| 
Applied Microbiology and Biotechnology (2019) 103: p. 1007-1019

\section{S2 Materials and methods}

\subsubsection{Reactor set-up and operational conditions}

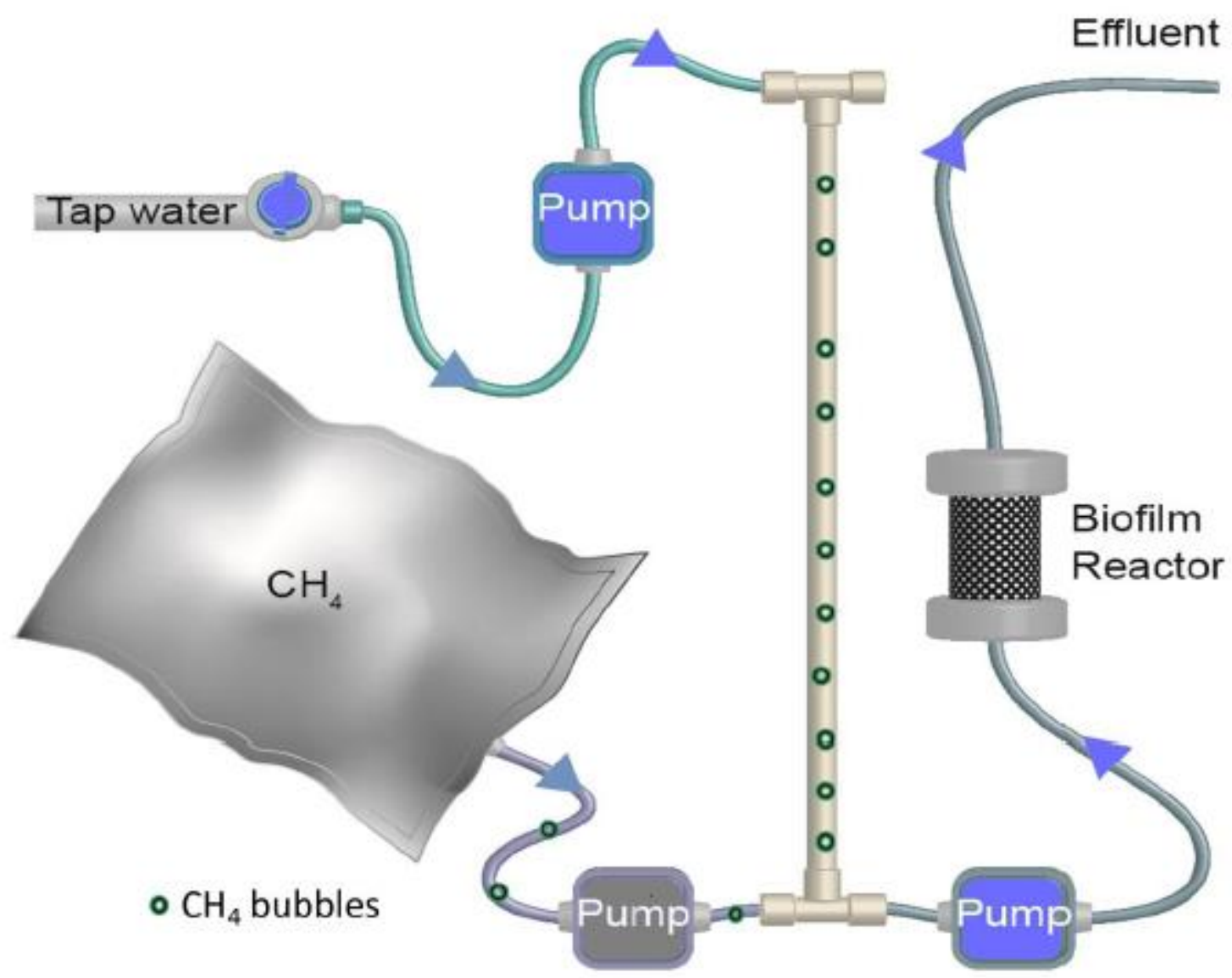

Figure S1. Methane-fed column reactor setup. Methane was dissolved in water in plastic columns and the mixture was directed into the upflow packed column reactor. 
Applied Microbiology and Biotechnology (2019) 103: p. 1007-1019

\section{S2.2 Microcosm experiments}

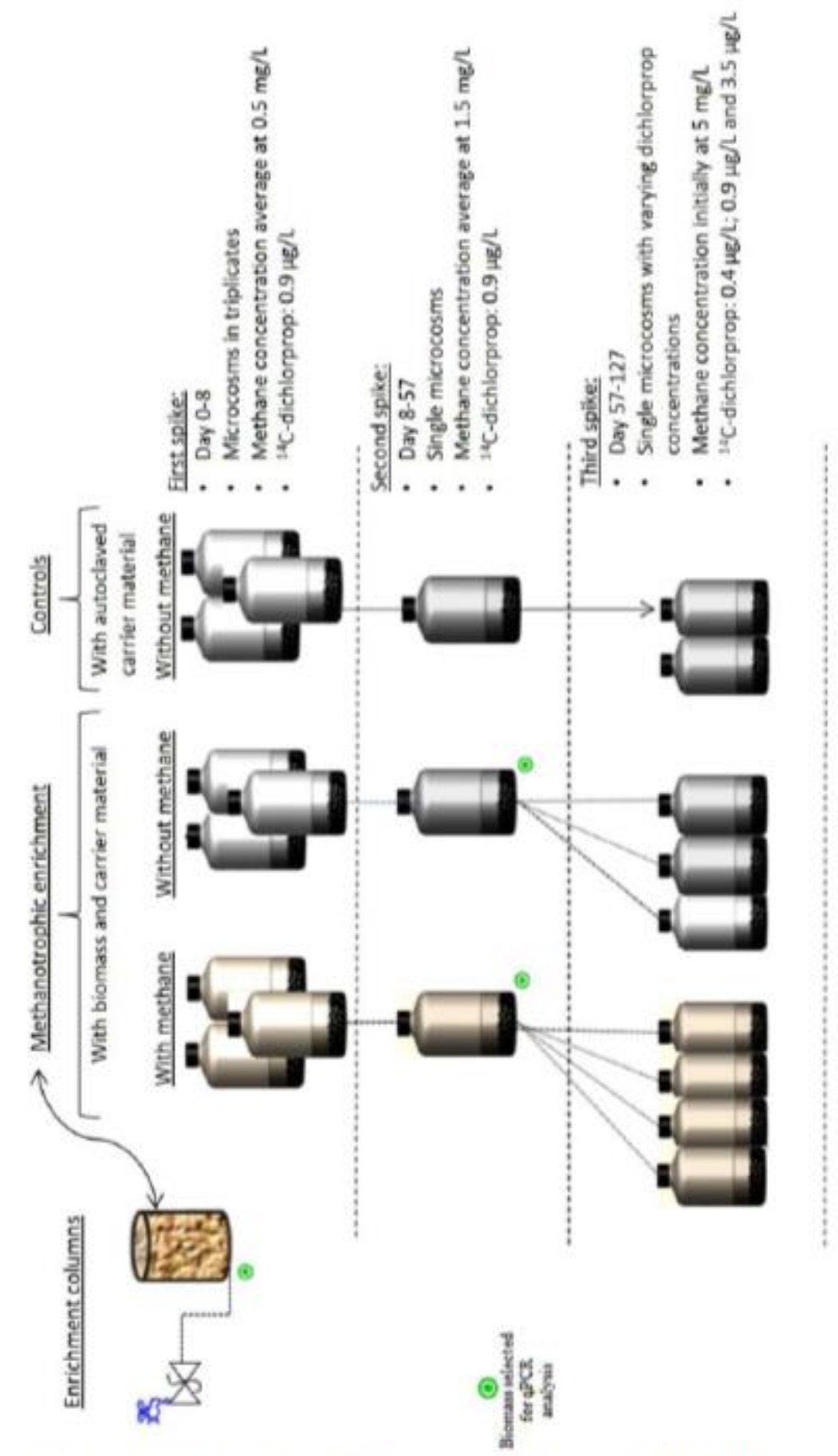

Figure S2. Summary of the experimental phases and conditions applied to the microcosms 
Applied Microbiology and Biotechnology (2019) 103: p. 1007-1019

S2.5 Estimation of methanotroph abundance using Real-time quantitative PCR ( $q P C R)$ and bacterial pmoA diversity by cloning sequencing

DNA was extracted from triplicate samples ( $0.5 \mathrm{~g}$ drained wet weight) using a MP FastDNA ${ }^{\mathrm{TM}}$ SPIN Kit (MP Biomedicals LLC, Solon, USA) according to manufacturer's instructions. The extracted DNA was eluted in $100 \mu 1$ Tris-EDTA buffer and its concentration and purity was estimated with a NanoDrop ${ }^{\mathrm{TM}}$ spectrophotometer (NanoDrop Technologies, DE, USA).

All bacteria (Eubacteria) and methanotrophs were quantified by real-time quantitative PCR (qPCR). For quantification of total Eubacteria, the $16 \mathrm{~S}$ rRNA gene was targeted with the $1055 \mathrm{~F}-1392 \mathrm{R}$ primer set (Ferris et al., 1996). Total number of methanotrophs were estimated by quantifying pmoA, which encodes a subunit of the particulate methane monooxygenase, using the specific primer set A189f-mb661r (Costello and Lidstrom, 1999). qPCR reactions were run in duplicate on a Chromo4 thermocycler with Opticon Monitor 3 software (Bio-Rad Laboratories, Inc., Hercules, $\mathrm{CA})$.

A qPCR reaction contained $12.5 \mu 1$ of $2 \times$ iQ SYBR Green Supermix (Bio-Rad Laboratories), 400 $\mathrm{nM}$ of each primer, $10 \mathrm{ng}$ template DNA and DNA/RNAase free water to $25 \mu 1$. The conditions were as follows: an initial $10 \mathrm{~min}$. denaturation at $95^{\circ} \mathrm{C}$, followed by 40 cycles of denaturation at $94{ }^{\circ} \mathrm{C}$ for $30 \mathrm{~s}$.; primer annealing at $55^{\circ} \mathrm{C}$ for $30 \mathrm{~s}$ and $60 \mathrm{~s}$ for Eubacteria and methanotrophs, respectively, and elongation at $72^{\circ} \mathrm{C}$ for $1 \mathrm{~min}$. The final step was a DNA extension at $72{ }^{\circ} \mathrm{C}$ for 10 min. Amplification efficiencies of $102.2 \%\left(R^{2}=0,996\right)$ and $99,1 \%\left(R^{2}=0,998\right)$ were obtained for Eubacterial $16 \mathrm{~S}$ rRNA and $p m o A$, respectively. qPCR results were quality checked by melting curve analysis after 40th cycle (gradient $0.2{ }^{\circ} \mathrm{C} / \mathrm{s}$, range $70-95^{\circ} \mathrm{C}$ ) (Ririe et al., 1997) and by agarose gel electrophoresis ( $1 \%$ agarose gel, $85 \mathrm{~V}, 50 \mathrm{~min}$.). These indicated that both reactions yielded single products.

The diversity of $p m o A$ was investigated by cloning and sequencing. PCR mixtures $(25 \mu 1)$ contained $10 \mathrm{ng}$ template DNA, $0.3 \mathrm{U}$ Taq polymerase (Sigma Aldrich), $12.5 \mathrm{pmol}$ of each A189f and mb661r primer, $50 \mathrm{mmol} \mathrm{KCl}, 30 \mathrm{mmol}$ Tris- $\mathrm{HCl}, 1.5 \mathrm{mmol} \mathrm{MgCl} 2$, and $12.5 \mathrm{mmol}$ deoxynucleoside triphosphates (dNTPs) (Sigma-Aldrich). PCR reaction was run under the conditions described above. The PCR products were analyzed on $1 \%$ (wt/vol) agarose gel, purified by PCR purification kit (Qiagene) and cloned into a pCR 2.1-TOPO vector and competent TOP10 Escherichia coli cells by a TOPO-TA cloning kit (Invitrogen), as described by the manufacturer. A partial sequencing of the obtained clones, using a forward A189f primer, was performed by GATC Biotech (Konstanz, Germany). The quality of the sequences was inspected with BioEdit software and poor-quality sequences were removed. The sequences (approx. $400 \mathrm{bp}$ ) were then compared to similar sequences at NCBI database. Sequences were aligned using ClustalW in the MEGA5 software package, and alignments were manually checked for consistency. Phylogenetic trees, including selected reference sequences from NCBI database, were constructed using the neighbor-joining method in MEGA 5 software. Furthermore, all sequences more than $97 \%$ similar to each other were grouped into operational taxonomic units (OTU) and a tree was constructed using Mothur software. 
Applied Microbiology and Biotechnology (2019) 103: p. 1007-1019

\begin{tabular}{cccc}
\hline \multicolumn{2}{c}{ Table S1 Accession numbers of determined sequences deposited in DDBJ. } \\
\hline Accession number & OTU's EntryID & OTU & Number of clones \\
\hline LC384897 & 14EB11_B05 & OTU12 & $\mathbf{2 5}$ \\
LC384898 & 14EB11_D05 & OTU13 & 1 \\
LC384899 & 14EB11_C11 & OTU8 & 1 \\
LC384900 & 14EB10_C03 & OTU8 & 1 \\
LC384901 & 14EB11_D07 & OTU8 & 1 \\
LC384902 & 14EB11_D11 & OTU8 & 3 \\
LC384903 & 14EB10_A11 & OTU4 & 2 \\
LC384904 & 14EB10_C01 & OTU3 & 3 \\
LC384905 & 14EB10_A01 & OTU1 & 2 \\
LC384906 & 14EB10_C02 & OTU7 & 1 \\
LC384907 & 14EB10_C08 & OTU6 & 4 \\
LC384908 & 14EB10_A03 & OTU1 & 6 \\
LC384909 & 14EB10_G08 & OTU10 & 1 \\
LC384910 & 14EB18_D05 & OTU10 & 1 \\
LC384911 & 14EB18_G05 & OTU11 & 3 \\
LC384912 & 14EB18_H06 & OTU9 & 7 \\
LC384913 & 14EB11_C07 & OTU2 & 2 \\
LC384914 & 14EB18_C12 & OTU2 & 21 \\
LC384915 & 14EB10_A08 & OTU2 & 7 \\
LC384916 & 14EB11_H08 & OTU14 & 1 \\
LC384917 & 14EB10_B04 & OTU5 & 1 \\
\hline
\end{tabular}




\section{S3 Results and Discussion}

S3.1 Reactor performance - methane removal and oxygen consumption

A

B

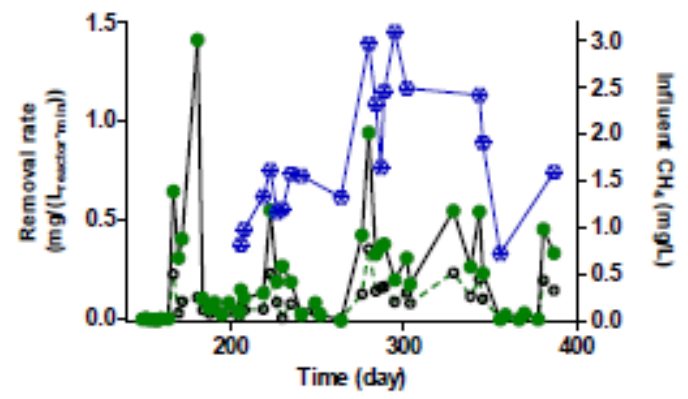

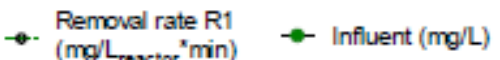

* $\mathrm{O} 2$ removal ( $\left.\mathrm{mg} /{ }_{\text {Lreactor }}{ }^{2} \mathrm{~min}\right)$

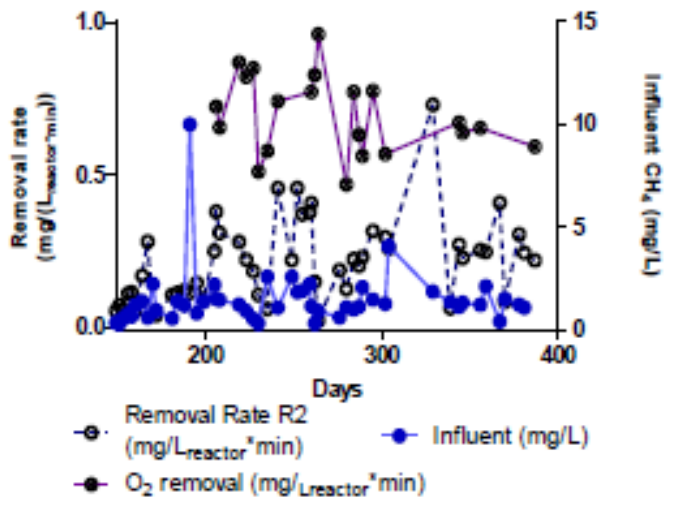

C
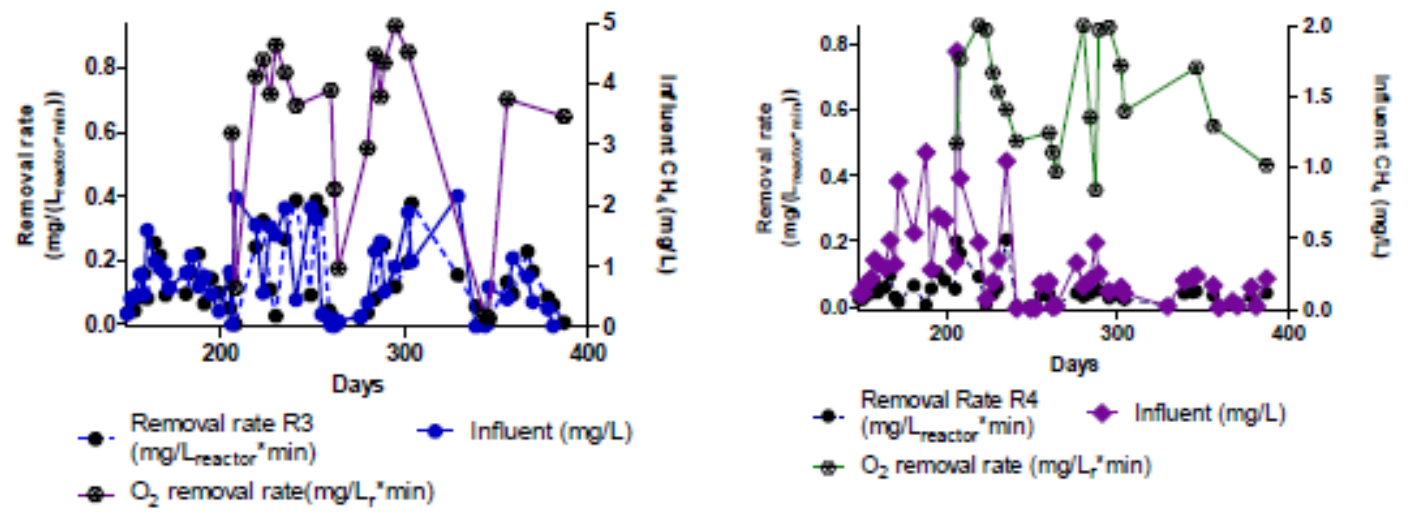

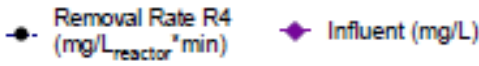

- $\mathrm{O}_{2}$ removal rate (mg/L'min)

Figure S3. Temporal profiles of methane removal rates and influent methane concentrations for every reactor in a separate panel. 


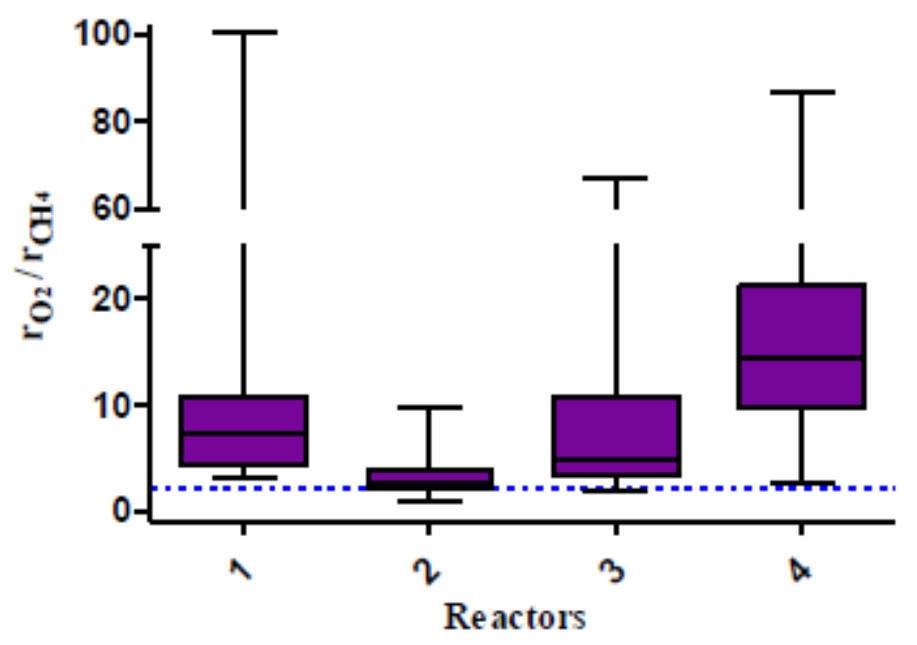

Figure S4. $\mathrm{O}_{2} / \mathrm{CH}_{4}$ removal rate ratio (mass-based) for all reactors during an indicative period of 200 days. The doted horizontal line marks the theoretical stoichiometry.

\section{S3.2 Pesticide removal in the column reactors}

We investigated whether the lack of detectable removal for most pesticides could be explained by the experimental conditions. In other words, whether the co-metabolic activity by methanotrophs would have been sufficient to observe clear pesticide removal in the reactors, considering the experimental variability. Therefore we calculated the minimum detectable pesticide removal, $\Delta \mathrm{C}_{\text {detect.pes }}$ which was compared to the expected removal, $\Delta \mathrm{C}_{\text {expect.pes }}$ in the system. The minimum detectable removal was calculated from the standard deviation on the inlet concentration (Table S2).

In mixed methanotrophic cultures, the observed normalized substrate preference, $S P$, for oxidation of methane over the trace contaminants has been reported to be $\geq 25$ methane molecules per molecule oxidized trace contaminant (Anderson and Mccarty, 1997; Hedegaard et al., 2018). Using the lowest reported substrate preference of 25 , resulted in very high calculated removal rates, respect,pes, of the system. From this, the maximal expected pesticide removal in the column reactors was calculated and compared to the removal needed for observing degradation (Table S2). Only for BAM and Isoproturon was the maximal expected pesticide removal larger than the minimum detectable removal in the column reactors. For all other investigated pesticides, the expected pesticide removal would not be detectable in the experimental system used here $\left(\Delta \mathrm{C}_{\text {detect.pes }}>\right.$ $\Delta \mathrm{C}_{\text {expect.pes}}$ ) (Table S2). Therefore, the lack of observed removal does not rule out the possibility for co-metabolic degradation. Indeed, we detected MCPA and MCPP removal in the starved methanotrophic column, in absence of competition with the primary substrate. 


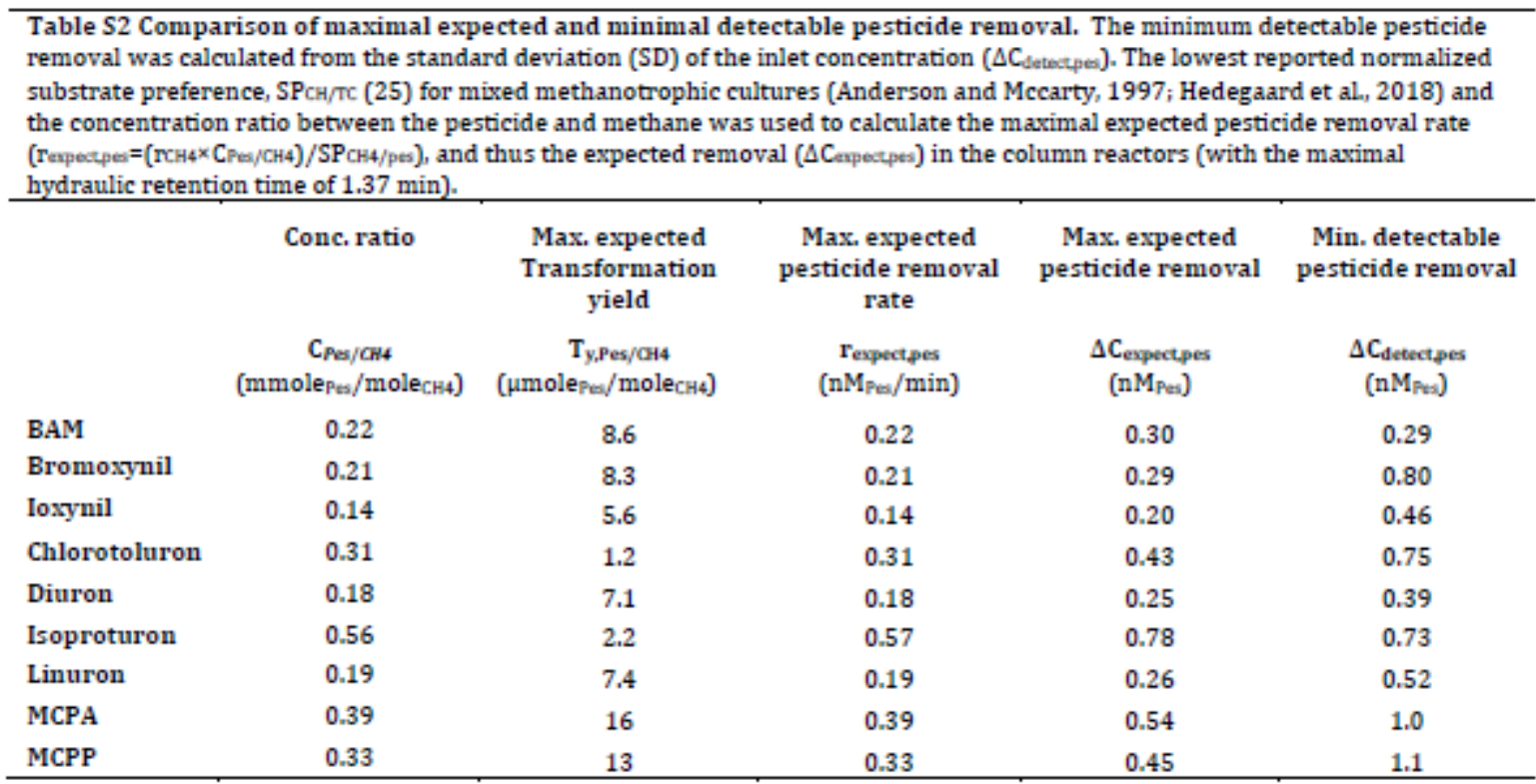

\section{S3.3 Dichlorprop removal and mineralization}

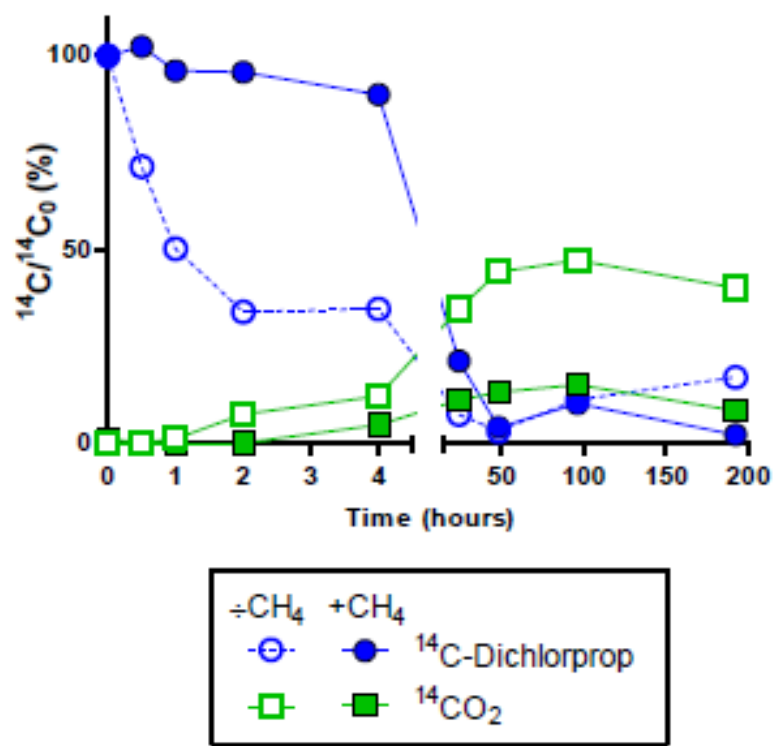

Figure S5 Dichlorprop removal and mineralization during the $2^{\text {vd }}$ spike (initial concentration $0.9 \mu \mathrm{g} / \mathrm{L}$ ). Filled symbols indicate methane presence and empty symbols its absence. 


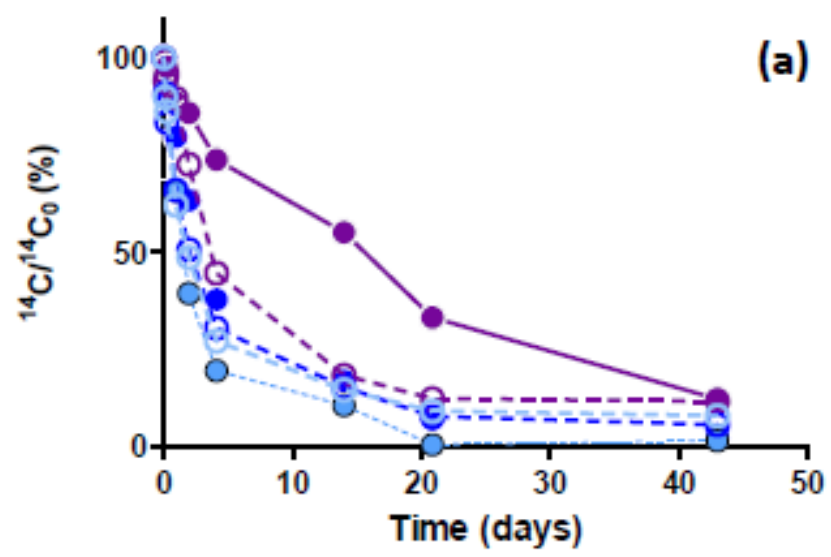

$$
\begin{aligned}
& \div \mathrm{CH}_{4}+\mathrm{CH}_{4} \\
& \text {-๑. - - } 0.4 \text { ug/L Dichlorprop } \\
& \text { ๑. } 0.9 \mathrm{ug} / \mathrm{L} \text { Dichlorprop } \\
& \text {-૭. - - } 3.5 \text { ug/L Dichlorprop }
\end{aligned}
$$

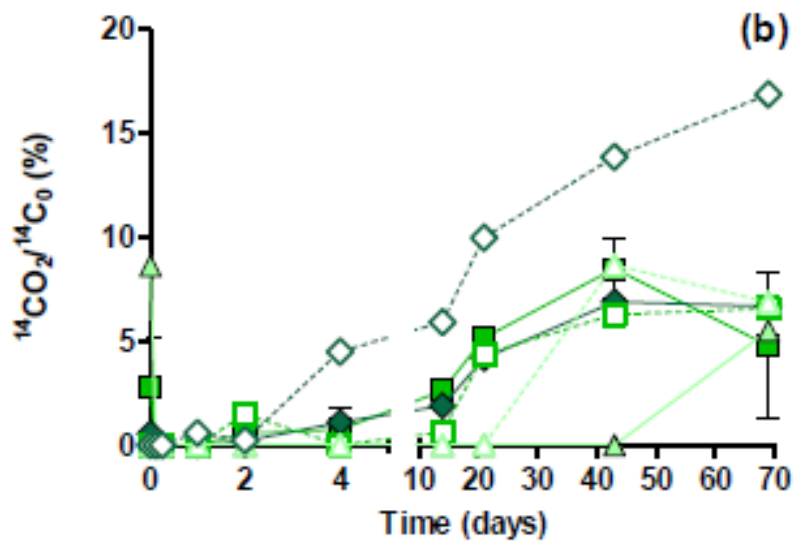

$$
\begin{aligned}
& \div \mathrm{CH}_{4}+\mathrm{CH}_{4} \\
& \triangle 0.4 \mu \mathrm{g} / \mathrm{L} \text { Dichlorprop } \\
& \square-0.9 \mu \mathrm{g} / \mathrm{L} \text { Dichlorprop } \\
& 3.5 \mu \mathrm{g} / \mathrm{L} \text { Dichlorprop }
\end{aligned}
$$

Figure S6 Dichlorprop removal and mineralization during the $3{ }^{\text {rd }}$ spike. A) ${ }^{14} \mathrm{C}$-dichlorprop removal and B) ${ }^{14} \mathrm{CO}_{2}$-production in presence $(5 \mathrm{mg} / \mathrm{L})$ and absence of methane. Biomass from microcosms used during $2^{\text {nd }}$ spike was split into the new microcosms before the $3^{\text {rd }}$ spike (biomass equal to $1 / 5$ of the biomass in $1^{\text {st }}$ and $2^{\text {nd }}$ spike). Only the experiment with ${ }^{14} \mathrm{C}$-dichlorprop at 0.9 $\mu \mathrm{g} / \mathrm{L}$ with methane was performedin duplicates). 
Applied Microbiology and Biotechnology (2019) 103: p. 1007-1019

\section{S3.4 Development of bacterial community over experimental phases}

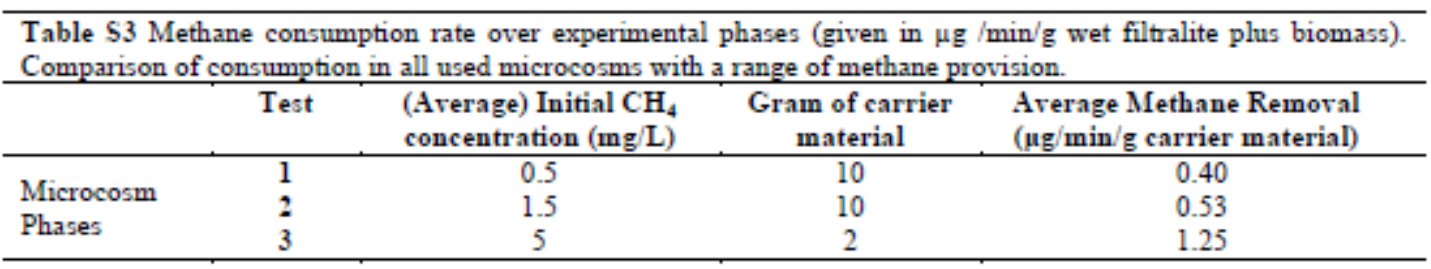

\begin{tabular}{|c|c|c|c|c|c|c|}
\hline Genus & $\begin{array}{l}\text { Phylogenetic } \\
\text { Position }\end{array}$ & $\begin{array}{c}\text { ICM- } \\
\text { arrangement } \\
\text { (type) }\end{array}$ & $\begin{array}{c}\text { Dominant } \\
\text { PLFA }\end{array}$ & $\begin{array}{c}\mathrm{C} \text { - } \\
\text { assimilatio } \\
\mathrm{n}\end{array}$ & Type of MMO & $\underset{\text { fixation }}{\mathrm{N}_{2^{-}}}$ \\
\hline Methylobacter & $\gamma$-Proteobacteria & stacks (I) & $16: \omega 1$ & RuMP & pMMO & no \\
\hline Methylocaldum & $\gamma$-Proteobacteria & stacks $(\mathrm{X})$ & $16: \omega 1$ & RuMP & pMMO & no \\
\hline Methylocapsa & $\alpha$-Proteobacteria & Type II & $18: \omega 1$ & Serine & pMMO & yes \\
\hline Methylocella & a-Proteobacteria & $\begin{array}{l}\text { peripheral } \\
\text { (II) }\end{array}$ & $18: \omega 1$ & Serine & sMMO & yes \\
\hline Methylococcus & $\gamma$-Proteobacteria & stacks (I-X) & $16: \omega 1$ & RuMP & pMMO & yes \\
\hline Methylocystis & $\alpha$-Proteobacteria & $\begin{array}{l}\text { peripheral } \\
\text { (II) }\end{array}$ & $18: \omega 1$ & Serine & sMMO/ pMMO & yes \\
\hline Methylomicrobium & $\gamma$-Proteobacteria & stacks (I) & $16: \oplus 1$ & RuMP & pMMO & no \\
\hline Methylomonas & $\gamma$-Proteobacteria & stacks (I) & $16: \omega 1$ & RuMP & pMMO & no \\
\hline Methylosinus & a-Proteobacteria & $\begin{array}{l}\text { peripheral } \\
\text { (II) }\end{array}$ & $18: \omega 1$ & Serine & sMMO/pMMO & yes \\
\hline Methylosphaera & y-Proteobacteria & stacks (I) & $16: \omega 1$ & RuMP & pMMO & no \\
\hline Methylothermus & y-Proteobacteria & n.d. & n.d. & n.d. & pMMO & n.d. \\
\hline
\end{tabular}

ICM: intracytoplasmatic membrane; n.d. not determined 


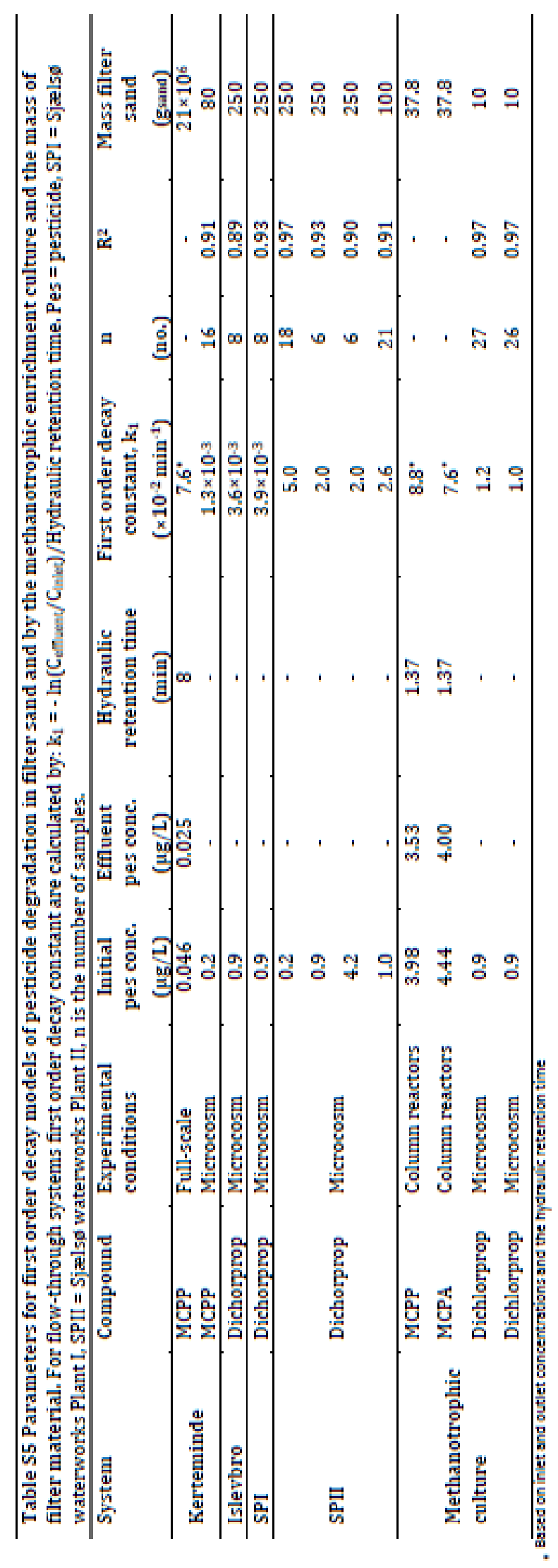

